Federal Reserve Bank of Minneapolis

Research Department Staff Report 154

April 1992

\title{
REAL EFFECTS OF MONETARY POLICY IN A WORLD ECONOMY
}

Preston J. Miller*

Richard M. Todd*

Federal Reserve Bank of Minneapolis

\begin{abstract}
We present a 2-country model with heterogeneous agents in which changes in a country's monetary policy affect real interest rates, relative prices of traded and nontraded goods and real exchange rates. Nontransitory real effects of monetary policy stem solely from a friction (country-specific reserve requirements) that generates separate demands for a country's money and bonds. Without violating the classical assumptions of individual rationality and flexible prices, the model's implications seem qualitatively in accord with the U.S. experience of the 1980s: a monetary policy tightening leading to a rise in the real interest rate and to an initial rise in the real value of the dollar which is subsequently reversed. In the model a monetary policy change leads to different welfare effects for agents born at different times, living in different countries, or participating on different sides of a market. The welfare of some agents can be affected more by relative price changes than by real interest rate changes.
\end{abstract}

*Subject to the usual disclaimers, we gratefully acknowledge the comments and suggestions of Mario Crucini, Jeremy Greenwood, David Orden, Victor Rios-Rull, Thomas Sargent, and seminar participants at Ecole des Hantes Études Commerciales, Montreal. David Orden's suggestion to consult the literature on the transfer problem was particularly helpful. Finally, we owe a special thank you to Neil Wallace for his comments on all aspects of our work.

The views expressed herein are those of the authors and not necessarily those of the Federal Reserve Bank of Minneapolis or the Federal Reserve System. 


\section{Introduction}

Events following the Federal Open Market Committee's policy change of 1979 focused attention on the transmission of monetary policy in open economies. Historical accounts and statistical evidence suggest that U.S. monetary policy shifted to a significantly more restrictive stance in the fall of 1979 (Blanchard 1984, Miller and Roberds 1991). A measure of U.S. monetary policy, the ratio of outside U.S. government debt to the U.S. monetary base, rose sharply at that time and remained high since then (Figure 1). After the policy change, real interest rates rose in the United States and stayed high (Figure 2). The value of the dollar rose, with most of the gain in real terms, and then fell (Figure 3). The trade deficit grew and then subsequently shrunk (Figure 4). The policy change and the accompanying real interest and exchange rate shifts also seemed to have distributional effects across different types of agents. Farmers, manufacturers, home builders and others who were heavy debtors or tradable goods producers complained that they were being hurt by monetary policy.

Various models address parts of these interrelated phenomena. The well-known sticky-price model of Dornbusch (1976) links monetary policy shocks to transitory movements in real interest rates and real exchange rates, including a pattern of exchange rate reversal that Dornbusch interprets as “overshooting." Frankel (1986) has reinterpreted Dornbusch's model to address relative price dynamics in a closed economy. However, neither of these models specifies a complete economy (in terms of preferences, endowments, and technologies) and thus neither has relationships that can be considered to be structural and neither is suited for direct analysis of welfare issues. Others have constructed general equilibrium models to study the effects of monetary policy on real exchange rates, but only in 2-period settings (Aizenman 1983, Greenwood 1984, and Frenkel and Razin 1987, Ch. 14). Miller and Wallace (1985), by contrast, examine the effects of monetary policy in a 
multicountry, dynamic general equilibrium model. However, their analysis ignores the real exchange rate and relative price effects of monetary policy, since they assume a single, world-tradable good. ${ }^{1}$

In this paper we explore how adding nontraded goods to a two-country version of the MillerWallace model affects the transmission of monetary policy to real interest rates, relative prices and real exchange rates, and the welfare of agents in the traded and nontraded sectors. The inclusion of nontraded goods introduces a relative price and real exchange rate channel for the transmission of monetary policy that was not present before. This channel, moreover, does not rely on sticky prices.

Adding nontraded goods to the Miller-Wallace model also alters the welfare consequences of a monetary policy change. In Miller-Wallace, agents who borrow and whose good is traded in world markets are clearly made worse off by a tightening in monetary policy due to a resulting rise in the real interest rate. In our model, the effects of higher real interest rates on borrowers can be mitigated or even reversed by a rise in the relative price of traded goods to nontraded goods.

Our model's setup has two countries, "home and foreign," each with a private and a public sector. The private sector has overlapping generations of agents who reside in one of two sectors. In one sector agents are endowed with the nontraded good and they tend to save. In the other sector agents are endowed with the traded good and they tend to borrow. The public sector has a budget authority that taxes and spends and a monetary authority that conducts open-market operations and imposes a reserve requirement against private savings. ${ }^{2}$ All debt, private and public, is perfectly substitutable and is traded in a world capital market. ${ }^{3}$ Money is held solely in the country that issues it and solely to satisfy the reserve requirement.

The interest rate and price effects of monetary policy changes stem primarily from five key features of the model: 
1. The presence of nontraded goods allows international shifts in wealth to affect relative prices and real exchange rates, as has been stressed in the static literature on the transfer problem (Chipman 1974, Orden 1986). ${ }^{4}$

2. Some agents hold nominal outside wealth (i.e., government debt) in the initial period. Thus, a policy change that affects the initial price level affects real wealth and, thereby, other real variables.

3. Strict monetarism holds. A country's price level is in fixed proportion to its money stock at all times. ${ }^{5}$

4. Unpleasant monetarist arithmetic prevails, in the sense that an open-market sale at date $t$ raises the rate of inflation from date $t+1$ forward. (Because the open-market sale implies more government bonds outstanding and a higher real interest rate, more seignorage is required to meet the increased interest payments on government bonds. $)^{6}$

5. The reserve requirement drives a wedge between the world real interest rate that borrowers pay and the lower real return that savers receive. (Savers' real rates of return are a weighted average of the real return on their country's money and the world real interest rate.) The size of this wedge depends on both the inflation rate and the reserve requirement ratio in the savers' country.

To understand how the model's key features lead to its monetary policy implications, consider first the effects of a monetary tightening at date 1 that takes the form of a permanent increase in the home country's ratio of bonds to money with no corresponding change in fiscal policy (noninterest spending or taxation). Our simulations, discussed below, show that this policy change initially has effects qualitatively similar to perceptions of U.S. experience in the early 1980s. The home country has disinflation, in the sense that the time 1 price level is less than it would have been. Real and 
nominal interest rates rise worldwide, and the real and nominal exchange rates of the home country also rise. The home country's trade deficit increases, and correspondingly foreigners increase their holdings of home-country debt. In subsequent periods, many of these effects reverse. Interest rates remain elevated, but disinflation gives way to increased inflation, home country exchange rates fall, and trade flows reverse.

These effects can be traced to the five key features above. The initial disinflation reflects the model's monetarist property, since raising the bond-money ratio when fiscal policy is unchanged involves an open-market sale that reduces the home country's money stock. This disinflation increases the real wealth of the initial old, since they hold nominal outside wealth. The open-market sale also boosts worldwide real interest rates by increasing the supply of bonds. The gains of the initial old imply a loss for future generations, who not only face higher interest rates but also a higher inflation tax due to unpleasant monetarist arithmetic. However, because these offsetting losses are distributed across time, aggregate wealth in the home country rises at time 1 . Thus, the home country increases its imports and consumption of the traded good, which is accompanied by a trade deficit, an increased relative price of the nontraded good, and real exchange rate appreciation.

In subsequent periods, the initial wealth effect of the monetary policy change dies out and the dominant effect becomes a difference in real rates of return to savers. ${ }^{7}$ The reason is that inflation rises more in the home country than in the foreign country, since the open-market sale reduces the home country's money stock, which is the base for its inflation tax. The wedge that inflation drives between the worldwide real interest rate that both home and foreign borrowers pay and the real return savers receive is thus wider in the home country, making home country savers less wealthy than foreign savers. Since borrowers in both countries are not directly affected by inflation and are affected symmetrically by interest rates, the international disparity in savers' wealth makes the foreign country wealthier overall. Because of this shift in wealth, the home country 
experiences declines in the relative price of nontraded goods and in its real exchange rate, and its trade balance shifts towards surplus.

The implications of these shifts in aggregate prices and quantities for agents' welfare are discussed along with our simulation results below. Here we note only that different agents can be affected differently by these changes in the real interest rate and relative prices. That's because the agents in the two sectors of the private economy are on opposite sides of the loan and goods markets.

We gain further insights about the channels of monetary policy transmission in our model by showing (in Appendix 2) that equilibria in our monetary model are also equilibria for a particular nonmonetary economy. In that economy, neither government issues money or bonds. Instead, each imposes on only its own residents, lump-sum taxes and transfers and an excise tax on intertemporal trade, payable upon delivery by those who purchase goods in the second period of life. The equivalence of the equilibria in the monetary and nonmonetary economies reveals that the effects of a change in a country's monetary policy cannot be replicated by changes in just its own lump-sum taxes and transfers. Because a monetary policy change affects the distortion introduced by the reserve requirement, the country's excise tax also must change. And, because one country's monetary policy affects the government financing requirement and the wedge between savers' and borrowers' rates of interest in the other country as well, the latter's taxes, lump-sum and excise, must change, too.

In the text that follows we describe the model, the nature of equilibria, and comparisons of equilibria for alternative monetary policies. 
The Model

\section{A. The Environment}

There are two countries, "home" and "foreign." Both have a private sector and a public sector. Both are populated by overlapping generations of agents who live two periods. At each integer date $t$ a new generation, generation $t$, appears. The members of generation $t$ are present at date $t$, when they are young, and at date $t+1$, when they are old.

Each generation is made up of two types. We refer to them as "service providers" and "farmers." Over time the number of each type of individual in each country is constant, and individuals can't switch types or countries. Without loss of generality, we assume that a single representative agent of each type is born at each date in each country.

The two types of individuals in each country have identical preferences and differ only with respect to their endowments. The preferences are assumed to be represented by a discounted log-linear utility function, $\mathrm{U}$, over service and food consumption in the two periods of an individual's life:

$$
\begin{aligned}
\mathrm{U}\left(\mathrm{c}_{\mathfrak{t}}\right) & \equiv \mathrm{U}\left(\mathrm{c}_{\mathfrak{t}}^{\mathrm{S}}(\mathrm{t}), \mathrm{c}_{\mathfrak{t}}^{\mathrm{F}}(\mathrm{t}), \mathrm{c}_{\mathfrak{t}}^{\mathrm{S}}(\mathrm{t}+1), \mathrm{c}_{\mathfrak{t}}^{\mathrm{F}}(\mathrm{t}+1)\right) \\
& =\theta \log \mathrm{c}_{\mathfrak{t}}^{\mathrm{S}}(\mathrm{t})+(1-\theta) \log \mathrm{c}_{\mathfrak{t}}^{\mathrm{P}}(\mathrm{t})+\delta\left[\theta \log \mathrm{c}_{\mathfrak{t}}^{\mathrm{S}}(\mathrm{t}+1)+(1-\theta) \log \mathrm{c}_{\mathfrak{t}}^{\mathrm{P}}(\mathrm{t}+1)\right]
\end{aligned}
$$

where $S$ is services, $F$ is food, a subscript $t$ refers to a member of generation $t$, an integer in parentheses is a date, $\theta$ is a parameter reflecting relative preferences for services versus food, and $\delta$ is a parameter reflecting the rate of time preference.

The endowments of the two types of individuals differ with respect to both the type of goods and the pattern of goods over time. The endowment of a generation $t$ service provider, $w_{t: S}$, is assumed to be 


$$
w_{t: S} \equiv\left[w_{t: S}^{S}(t), w_{t: S}^{P}(t), w_{t: S}^{S}(t+1), w_{t: S}^{P}(t+1)\right]=\left[w_{t}^{S}(t), 0,0,0\right],
$$

where $w_{t}^{s}(t)>0$. Service providers are endowed with all of their country's services in their first period of life, and with nothing else.

The endowment of a generation $t$ farmer, $\mathrm{w}_{\mathrm{t}: \mathrm{F}}$, is assumed to be:

$$
w_{t: F} \equiv\left[w_{t: F}^{S}(t), w_{t: F}^{P}(t), w_{t: P}^{S}(t+1), w_{t: F}^{F}(t+1)\right]=\left[0, w_{t}^{P}(t), 0, w_{t}^{P}(t+1)\right],
$$

where $w_{t}^{P}(t+1)>w_{t}^{P}(t) \geq 0$. Farmers are endowed with some positive amount of food in their second period of life and with a lesser amount, perhaps zero, in the first period.

The preferences and the time-pattern of endowments apply to both countries, but the amounts of endowments can differ between the two. To distinguish the countries, we use a superscript asterisk on foreign variables or functions. For example, foreign preferences are represented by $\mathrm{U}\left(\mathrm{c}_{\mathrm{t}}^{*}\right)$.

The pattern of endowments is intended to roughly proxy production, which is not included in our model. In a loose sense we think of our service providers as suppliers of labor-intensive goods with a relatively short production lag. Hence, their endowment is concentrated in the first period of life. Similarly, we think of our farmers as suppliers of a capital-intensive good subject to a relatively long production lag that requires high initial investment. Hence, their endowment is concentrated in the second period of life. There is no storage.

Because of the different endowment patterns, in equilibrium service providers lend and farmers borrow. We assume all private debt is in the form of one-period discount bonds, $B^{\mathrm{P}}$. We think of these as nominal (nonindexed) bonds denominated in the currency of the country of the issuer. 
Farmers are distinguished by two characteristics in our model. One is that they are borrowers. A second is that only their good is world traded. While services and food can be purchased and sold within a country, only food can be traded between countries. These assumptions reflect the relative capital intensity of certain traded goods sectors, such as agriculture and traditional manufacturing industries, that have figured prominently in debates over the welfare effects of U.S. monetary policy.

In addition to a private sectór, both countries have a public sector. The public sector has a fiscal authority that consumes some amounts of its country's service and food and levies lump-sum real taxes, quoted in food units, on service providers and farmers. Public sector consumption does not affect agents' pre-tax endowments or utilities. We assume that the public sector's total consumption always matches or exceeds its total lump-sum tax revenue. (This permanent deficit assumption implies that, in steady states, inflation must be positive to generate the seignorage needed to finance government deficits.) A country's budget policy is defined by the fiscal authority's real consumption of services and food, $\mathrm{g}^{\mathrm{S}} \geq 0$ and $\mathrm{g}^{\mathrm{F}} \geq 0$, respectively; by its lump-sum taxes; and by its issue of one-period discount bonds, $\mathbf{B}^{\mathrm{G}}$, to finance the deficit. However, since lump-sum taxes are fixed throughout the analysis, we set them to zero.

Each public sector also has a monetary authority that engages in open-market operations and imposes a reserve requirement. Open-market operations are conducted by exchanging fiat money for government bonds, and the reserve requirement is specified by the fraction of residents' gross nominal savings that must be held in the form of money. A country's monetary policy is defined by the ratio of government bonds to money, $\beta$, and by the reserve requirement, $\lambda$. Government bonds are traded in a world capital market, but in equilibrium money is held only by lenders in its country of issue. 


\section{B. Individual Optimization Problems}

We describe the optimization problems of the old at date 1 (generation 0 ) and of the young at all dates (generations $t>0$ ). We only consider the home country, since foreigners solve parallel problems. Individuals take prices as given and young agents born at date 1 or later have perfect foresight with respect to prices in their second period of life.

The old at $\mathrm{t}=1$ maximize:

$$
\theta \log c_{0}^{S}(1)+(1-\theta) \log c_{0}^{\mathrm{F}}(1)
$$

subject to

$$
Q(1) c_{0}^{S}(1)+c_{0}^{F}(1)=A_{0},
$$

where $Q(1)=\left[p^{\mathrm{s}}(1) / \mathrm{p}^{\mathrm{P}}(1)\right]$ is the relative price of services to food at date 1 . For old service providers, $A_{0}=A^{S} / p^{F}(1)$, where $A^{S}>0$ is a given nominal value of assets and $p^{P}(1)$ is the first period price of food, an endogenous variable. The assets consist of some combination of home country money and private and public bonds from either country. For old farmers, $A_{0}=w_{0}^{P}(1)-$ $D_{0} / p^{F}(1)$, where $D_{0}>0$ is a given nominal value of private debt consisting of bonds issued earlier. Note that for both types of old agents at $t=1$, the real value of $A_{0}$ depends on $\mathrm{p}^{\mathrm{F}}(1)$, an endogenous variable subject to the effects of unanticipated monetary policy changes in period 1.

The optimization problem generates the usual Cobb-Douglas-utility demand functions:

$$
\mathfrak{E}_{0}^{\mathrm{S}}(1)=\theta \mathrm{A}_{0} / \mathrm{Q}(1)
$$

and

(2b) $\quad \mathfrak{C}_{0}^{\mathrm{F}}(1)=(1-\theta) \mathrm{A}_{0}$,

where $A_{0}$ takes on the values specified above for old service providers and farmers, respectively. Agents born at dates $t \geqq 1$ maximize (1) subject to 
$W(t)=Q(t) c_{t}^{S}(t)+c_{t}^{F}(t)+\left[Q(t+1) c_{t}^{S}(t+1)+c_{t}^{F}(t+1)\right] /(1+i(t))$,

where

$$
\begin{aligned}
& W(t)= \begin{cases}Q(t) w_{t}^{s}(t), & \text { for service providers } \\
w_{t}^{F}(t)+\frac{w_{t}^{P}(t+1)}{1+\rho(t)}, & \text { for farmers }\end{cases} \\
& 1+i(t)= \begin{cases}1+\rho_{s}(t), & \text { for service providers } \\
1+\rho(t), & \text { for farmers }\end{cases} \\
& r(t) \equiv \text { the nominal interest rate on one-period bonds issued at } t ; \\
& \pi^{P}(t) \equiv p^{P}(t+1) / p^{F}(t)-1 \text {, the rate of food price inflation from } t \text { to } t+1 \text {; } \\
& \rho(t) \equiv[1+r(t)] /\left[1+\pi^{\mathrm{F}}(t)\right]-1 \text {, the real rate of return on one-period bonds issued at } t \\
& \rho_{z}(t) \equiv[1+(1-\lambda(t)) r(t)] /\left[1+\pi^{\mathrm{F}}(\mathrm{t})\right]-1 \\
& =(1-\lambda(t)) \rho(t)+\lambda(t)\left[-\pi^{\mathrm{P}}(\mathrm{t}) /\left(1+\pi^{\mathrm{F}}(\mathrm{t})\right)\right],
\end{aligned}
$$

the real rate of return on savings at $t$.

Note that the real rate of return on savings doesn't depend just on the real rate of return on bonds. Because lenders are legally required to hold a fraction of their assets as domestic currency, their real net rate of return is a weighted average of $\rho(t)$, the real net return on bonds, and $-\pi^{\mathrm{P}}(\mathrm{t}) /\left(1+\pi^{\mathrm{P}}(\mathrm{t})\right)$, the real net return on money. The weights are $(1-\lambda(\mathrm{t}))$ and $\lambda(\mathrm{t})$, respectively, where $\lambda(t)$ is the fraction of their assets that savers must hold in the form of money. Thus, the wedge between the real return to lenders and the real interest rate paid by borrowers depends both on the reserve requirement and on the inflation rate.

The optimization problem again generates typical Cobb-Douglas-utility demand functions: 
(3a) $\quad c_{t}^{s}(t)=\left[\frac{\theta}{1+\delta}\right] W(t) / Q(t)$

(3b) $\varepsilon_{\mathfrak{t}}^{\mathrm{F}}(\mathrm{t})=\left[\frac{1-\theta}{1+\delta}\right] \mathrm{W}(\mathrm{t})$,

$$
\begin{aligned}
& \mathcal{\varepsilon}_{\mathrm{t}}^{\mathrm{s}}(\mathrm{t}+1)=\left[\frac{\theta \delta}{1+\delta}\right]\left[\frac{\mathrm{W}(\mathrm{t})}{\mathrm{Q}(\mathrm{t}+1)}\right](1+\mathrm{i}(\mathrm{t})) \\
& \mathcal{E}_{\mathfrak{t}}^{\mathrm{F}}(\mathrm{t}+1)=\left[\frac{(1-\theta) \delta}{1+\delta}\right][\mathrm{W}(\mathrm{t})](1+\mathrm{i}(\mathrm{t})) .
\end{aligned}
$$

\section{Government Budget Constraint}

The government at date $t$ pays for current expenditures and the retirement of last period's bonds and money by issuing new bonds and money:

$$
\mathbf{p}^{S}(t) g^{S}(t)+p^{F}(t) g^{F}(t)+B^{G}(t-1)+H(t-1)=P^{B}(t) B^{G}(t)+H(t)
$$

where $P^{B}(t)$ is the nominal price of government bonds, $P^{B}(t)=1 /(1+r(t))$, $B^{G}(t)$ is the total nominal face value at time $t+1$ of government bonds issued at time $t$, and $H(t)$ is the total quantity of money.

Let the real value of bonds and money in terms of food at date $t$ be defined respectively by $\mathrm{b}^{\mathrm{G}}(\mathrm{t}) \equiv \mathrm{P}^{\mathrm{B}}(\mathrm{t}) \mathrm{B}^{\mathrm{G}}(\mathrm{t}) / \mathrm{p}^{\mathrm{F}}(\mathrm{t})$ and $\mathrm{h}(\mathrm{t}) \equiv \mathrm{H}(\mathrm{t}) / \mathrm{p}^{\mathrm{P}}(\mathrm{t})$. In addition, let $\beta(\mathrm{t}) \equiv \mathrm{B}^{\mathrm{G}}(\mathrm{t}) / \mathrm{H}(\mathrm{t})$. Then the government budget constraint can be written

$$
\mathrm{Q}(\mathrm{t}) \mathrm{g}^{\mathrm{S}}(\mathrm{t})+\mathrm{g}^{\mathrm{F}}(\mathrm{t})=\left[\frac{1+\mathrm{r}(\mathrm{t})+\beta(\mathrm{t})}{1+\mathrm{r}(\mathrm{t})}\right] \mathrm{h}(\mathrm{t})-\frac{[1+\beta(\mathrm{t}-1)]}{\left[1+\pi^{\mathrm{F}}(\mathrm{t}-1)\right]} \mathrm{h}(\mathrm{t}-1) .
$$

\section{Price Levels, Exchange Rates, and Interest Rates}

We first define selected price variables and then express relationships among them which must hold in equilibrium. The aggregate price level in a particular country is defined as: 


$$
P(t) \equiv P^{s}(t)^{\theta} P^{F}(t)^{(1-\theta)}
$$

a measure of the minimal cost of one unit of utility.

The nominal exchange rate e defines how many units of the foreign country's currency are exchanged for one unit of the home country's currency. By the Law of One Price applied to the traded good, it follows that

$$
e(t) p^{F}(t)=p^{F^{*}}(t), \text { or } e(t)=p^{F^{*}}(t) / p^{F}(t)
$$

The real exchange rate then is defined as the nominal exchange rate divided by the ratio of the price levels, or:

$$
\overline{\mathrm{e}}(\mathrm{t}) \equiv \mathrm{e}(\mathrm{t}) /\left[\mathrm{P}^{*}(\mathrm{t}) / \mathrm{P}(\mathrm{t})\right]=\left[\mathrm{Q}(\mathrm{t}) / \mathrm{Q}^{*}(\mathrm{t})\right]^{\theta}
$$

Since private and government bonds within a country are perfect substitutes, their nominal (as well as real) rates of return must be the same in equilibrium-a fact we already used in stating the optimization problems. Moreover, because domestic and foreign bonds are perfect substitutes, it follows that the real interest rates in equilibrium must be the same in each country:

$$
\frac{1+r(t)}{1+\pi^{p}(t)} \equiv 1+\rho(t)=1+\rho^{*}(t) \equiv \frac{1+r^{*}(t)}{1+\pi^{F *}(t)}
$$

We refer to this single real rate as $\rho(t)$.

\section{E. Equilibrium}

A market equilibrium is defined as an allocation of goods and sequences of prices such that at each date the allocation solves individual optimization problems given the prices, the quantities and prices are consistent with the two governments' budget constraints, and markets clear. There are six markets in the model: two world markets in food and bonds, and four domestic markets in 
country-specific services and money. By Walras's Law we eliminate separate consideration of the world bond market. In the remaining markets five price sequences are determined: the world real interest rate $(\rho)$, the relative price of services to food in each country ( $Q$ and $Q^{*}$ ), and the rate of change of food prices in each country $\left(\pi^{\mathrm{F}}\right.$ and $\left.\pi^{\mathrm{F}}\right)$. All equilibrium quantities and prices can be derived from those five sequences, which in turn can be derived by equating demand and supply in the goods and money markets, as follows:

(7) Home Services Market

$$
w_{t}^{S}(t)=\hat{c}_{t-1: S}^{S}(t)+\hat{c}_{t: S}^{S}(t)+\hat{c}_{t-1: F}^{S}(t)+\hat{c}_{t: F}^{S}(t)+g^{S}(t)
$$

where subscripts $S$ and F refer to consumption by, respectively, service and food providers.

(8) Foreign Services Market (Parallel to (1))

(9) World Food Market

$$
\begin{aligned}
& w_{t-1}^{F}(t)+w_{t}^{F}(t)+w_{t-1}^{F^{*}}(t)+w_{t}^{F^{*}}(t) \\
& =c_{t-1: s}^{F}(t)+c_{t: S}^{F}(t)+\hat{c}_{t-1: P}^{F}(t)+c_{t: P}^{F}(t)+g^{F}(t) \\
& \quad+c_{t-1: s}^{F *}(t)+c_{t: s}^{F^{*}}(t)+c_{t-1: P}^{F *}(t)+c_{t: P}^{F^{*}}(t)+g^{F^{*}}(t)
\end{aligned}
$$

(10) Home Money Market

$$
H(t)=\lambda(t)\left[p^{S}(t) w_{t}^{S}(t)-p^{S}(t) \hat{C}_{t: s}^{S}(t)-p^{F}(t) \mathcal{E}_{t: s}^{F}(t)\right]
$$

\section{(11) Foreign Money Market (Parallel to (4))}

The money market equilibrium conditions assume that the reserve requirements are binding; that is, money is held only to satisfy the reserve requirements. Since we consider only equilibria for which $\rho>0$, bonds will dominate money in rate of return and the assumption that reserve requirements bind will be warranted. 
We can express the five equilibrium conditions in terms of the five sequences $\rho, Q, Q^{*}, \pi^{\mathrm{P}}$, and $\pi^{\mathrm{F} *}$ and basic parameters: preferences, endowments, and policies. (See Appendix 1.) We do this by substituting into conditions (7)-(11) the price relationships, government budget constraints, and demand functions (2)-(6) derived in the previous sections.

We note that the initial $(t=1)$ equilibrium will depend on what we assume about the distribution of wealth among the initial old. In particular, aggregate real demand of the initial old is proportional to $\left[\mathrm{A}^{S}-\mathrm{D}_{0}+\mathrm{p}^{\mathrm{F}}(1) \mathrm{w}_{0}^{\mathrm{P}}(1)\right] / \mathrm{p}^{\mathrm{P}}(1)$ in the home country and to $\left[\mathrm{A}^{S^{*}}-\mathrm{D}_{0}^{*}+\right.$ $\left.\mathrm{p}^{\mathrm{p*}}(1) \mathrm{w}_{0}^{\mathrm{F*}}(1)\right] / \mathrm{p}^{\mathrm{P*}}(1)$ in the foreign country. We limit our attention to initial wealth distributions in which there is no international indebtedness, so that $A^{S}-D_{0}=H(0)+B^{G}(0)$ and $A^{S^{*}}-D_{0}^{*}=$ $\mathrm{H}^{*}(0)+\mathrm{B}^{\mathrm{G}^{*}}(0)$. This assumption is convenient, in the sense that it avoids the issue of specifying whether initial cross-country debt is specified in home currency units, foreign currency units, or real units.

Much of our analysis relies on properties of steady states. For steady states, the time invariant versions of equations (7)-(11), which are given as equations (A.1ss)-(A.5ss) in Appendix 1 , can be reduced to a cubic polynomial in $\rho^{s s}$, the steady-state real interest rate. The conditions we impose on parameter values in our existence and uniqueness theorems guarantee that this polynomial has a single positive root, which is easy to compute. All other steady-state variables are then solved for as functions of $\rho^{3 s}$.

\section{F. Policy Analysis}

\section{Methodology}

We compute dynamic equilibrium paths following changes in policy. We assume that initially the economy is in a steady state. To justify this assumption we require that initially our parameters and policies satisfy the sufficient conditions for the existence and uniqueness of steady-state equilib- 
ria. We then perturb a policy parameter beginning at $t=1$ to a new value which is consistent with a new steady-state equilibrium. We compute the dynamic path of the economy as it moves from the initial steady state to the new one. ${ }^{8}$ Because of the complexity of the model, we are forced to use numerical methods, as did Rotemberg (1985) and Auerbach-Kotlikoff (1987) in similar contexts.

To solve for a dynamic equilibrium path, we solve a sequence of simultaneous equation systems. ${ }^{9}$ Initial values and first-period parameter values give rise to a set of simultaneous equations that can be solved for $\rho(1), Q(1)$, and $Q^{*}(1)$. Taking these as given, a second simultaneous system, involving both first- and second-period parameters, determines $\pi^{P}(1), \pi^{\mathrm{F}^{*}}(1), \rho(2), \mathrm{Q}(2)$, and $\mathrm{Q}^{*}(2)$. This second system is then used repeatedly to solve forward for $\pi^{\mathrm{F}}(\mathrm{t}), \pi^{\mathrm{F}^{*}}(\mathrm{t}), \rho(t+1), Q(t+1)$, and $\mathrm{Q}^{*}(\mathrm{t}+1)$, taking $\rho(\mathrm{t}), \mathrm{Q}(\mathrm{t})$, and $\mathrm{Q}^{*}(\mathrm{t})$ as given, for $\mathrm{t}=2,3,4, \ldots$. Paths for all other variables can be computed from the paths for $\rho, \mathrm{Q}, \mathrm{Q}^{*}, \pi$, and $\pi^{*}$.

Our policy experiments consider the effects of a tightening in the home country's monetary policy. The tightening is taken to be a once-and-for-all 1 percent increase in either $\beta$ or $\lambda$ at $t=1$, keeping all other parameters fixed at their initial steady-state values. ${ }^{10}$ After computing the initial steady state, we then compute the economy's equilibrium under the new policy for periods 1-7 and compare the new equilibrium values of each variable at each date with the corresponding initial steady-state value of the variable. The difference between the two values gives the effect of a 1 percent permanent tightening of home-country monetary policy. We limit our computations to 7 periods because by then the disturbed economy has nearly settled into a new steady state.

Because the impacts calculated in this way depend on the initial parameter values, we numerically check their sensitivity to the choice of parameters. We do this by repeating the computations outlined above for approximately 500 parameter vectors randomly selected from the set of parameters for which the theorems in our Appendix 1 guarantee the existence and uniqueness of a steady-state equilibrium. ${ }^{11}$ Because the issue of how to choose plausible parameters for our 
model is unsettled and because we wish to explore as broadly as possible all the properties of our model, we use a uniform probability distribution over this set instead of a distribution concentrated on a particular subset. ${ }^{12}$

Our existence and uniqueness theorems do impose some constraints on the cases we consider, however. Most notably, our uniqueness theorem is valid only when the home and foreign countries have identical parameters, except that their endowments and government consumptions may differ by a scale factor. In all our calculations, therefore, the two countries have identical preferences $\left(\theta=\theta^{*}, \delta=\delta^{*}\right)$, initially identical monetary policies $\left(\beta=\beta^{*}, \lambda=\lambda^{*}\right.$, for all $\left.\mathrm{t}\right)$, and proportional endowments, government consumptions, and initial real debts $\left(w_{1}^{\mathrm{P}}=\mathrm{zw}_{1}^{\mathrm{P}^{*}}, \mathrm{w}_{2}^{\mathrm{P}}=\mathrm{zw}_{2}^{\mathrm{P}^{*}}, \mathrm{w}_{1}^{\mathrm{S}}=\mathrm{zw}_{1}^{\mathrm{S}}\right.$, $\mathrm{g}^{\mathrm{F}}=\mathrm{zg}^{\mathrm{F}^{*}}$, and $\mathrm{g}^{\mathrm{S}}=\mathrm{zg}^{\mathrm{S}^{*}}$ for all $\mathrm{t}$ and $\mathrm{B}^{\mathrm{G}}(0)=\mathrm{zB}^{\mathrm{G}^{*}}(0), \mathrm{H}(0)=\mathrm{zH}^{*}(0), \mathrm{A}^{\mathrm{s}}=\mathrm{zA}^{\mathrm{S}}$, and $\mathrm{D}_{0}=\mathrm{zD}_{0}^{*}$, where $\mathrm{z}$ is the factor of proportionality). This symmetry up to a scale factor implies that in the initial steady state there are no net trade flows. This justifies the assumption we made above that no assets are internationally traded in the initial steady state, so that the initial conditions do not impose an international debt burden on either country.

We use the scale factor to conduct both large and small country versions of our policy experiments. In the large country experiments, which we think of as roughly appropriate to the United States, we scale the home country to be the same size $(z=1)$ as the foreign country (e.g, ROW). In the small country experiments, which we think of as roughly appropriate for, say, Canada, we scale the home country to be a tenth the size $(z=0.10)$ of the foreign country. Note that our use of the term "small country" is somewhat nonstandard, in that our small country is not atomistic and does affect world prices to some degree.

In order to explain the welfare effects of policy changes, we make use of a decomposition of the change in agents' indirect utility functions into terms corresponding to real rates of return and relative prices, respectively. Note that for given endowments we can express the lifetime utility of 
home country service providers in terms of $\left(\rho_{s}, Q\right)$, the lifetime utility of home country farmers in terms of $(\rho, Q)$, and similarly for the lifetime utilities of foreign service providers and farmers. Exploiting the log-linearity of the utility function, we can then decompose any change in the utility of, respectively, service providers and farmers into the following rate of return component (first term in brackets) and relative price component (second term in brackets):

$$
\begin{aligned}
\Delta U^{s}= & \left\{\delta \ln \left[\left(1+\tilde{\rho}_{s}(t)\right) /\left(1+\rho_{s}(t)\right)\right]\right\} \\
& +\{(1+\delta \theta) \ln (\tilde{Q}(t) / Q(t))-\delta \theta \ln (\tilde{Q}(t+1) / Q(t+1))\} \\
\Delta U^{F}= & \left\{\delta \ln \left[\frac{1+\tilde{\rho}(t)}{1+\rho(t)}\right]+(1+\delta) \ln \left[\frac{w_{t}^{F}(t)+w_{t}^{F}(t+1) /(1+\tilde{\rho}(t))}{w_{t}^{F}(t)+w_{t}^{P}(t+1) /(1+\rho(t))}\right]\right\} \\
& -\{\theta \ln [\tilde{Q}(t) / Q(t)]+\delta \theta[\tilde{Q}(t+1) / Q(t+1)]\} .
\end{aligned}
$$

In these expressions, $\sim$ denotes a value in the post-policy-change equilibrium and variables without $\sim$ are from a continuation of the initial steady state. Note that the rate-of-return term for farmers depends on the worldwide real interest rate only, while for service providers it also depends, through $\rho_{s}$, on the inflation rate in their country of residence. Below we judge the relative size of the real interest rate and relative price effects in terms of how they affect welfare.

Because there are so many results to report and interpret, we focus our discussion on just one experiment: a rise in $\beta$ in the large country case. We have previously discussed how five key features of the model lead to its main implications for prices and interest rates in the initial period, transition period, and long run. So, for this one experiment we further focus our discussion on exceptions (effects that occur for a minor subset of parameter values) and on welfare effects. For the other experiments, we just briefly indicate and explain any differences from the $\beta$-large country experiment. We conclude this section with observations on transition paths. 


\section{Effects of a Higher $\beta$ (Open-Market Sale)-Large Country Case}

The major macroeconomic effects from a monetary policy tightening $(\% \Delta \beta=1, \mathrm{z}=1)$ are illustrated in Figure $5 .{ }^{13}$ For a given initial parameter set the lines indicate the differences in equilibrium paths for selected variables when $\beta$ is increased by 1 percent at $t=1$. The typical macroeconomic effects were described in the introduction and explained as consequences of five key features of the model.

The typical results hold for all parameter sets with two exceptions (Table 1, top panel). In 5 percent of the cases the foreign inflation rate declines as $\beta$ rises. In all cases the rise in $\beta$ causes the real interest rate to rise and that by itself requires a higher foreign inflation rate. But in 5 percent of the cases, real private savings and money holdings increase by enough to offset that effect. They increase because the relative price of savers' endowments rises.

In 10 percent of the cases the real rate of return on savings in the home country declines as $\beta$ rises. That happens because that rate of return is a weighted average of the real interest rate on bonds and the real rate of return on money $\left(-\pi^{F} /\left(1+\pi^{F}\right)\right)$, and in these cases the rise in inflation more than offsets the rise in the real interest rate.

The typical welfare effects from the monetary tightening for the same parameter set can be seen in the bottom panel of Table 1. All the welfare effects can be explained in terms of changes in initial prices and in the paths of real interest rates and relative prices (as on p. 17). The decline in the initial price level in the home country dominates the welfare results for the initial old there. Initial old farmers lose because of the increased real value of their nominal debt to initial old savers. ${ }^{14}$ These savers reap further gains from the increased real value of their holdings of nominal government bonds. The opposite occurs in the foreign country, where the low relative price of nontraded goods cuts real savings, hence also real money demand, and leads to an initial price level jump. Among the young, higher real interest rates typically benefit savers and harm borrowers. 
Initially these effects are amplified at home, and moderated but not overturned abroad, by relative price changes. The opposite occurs in later periods, as the direction of relative price changes reverses.

The typical results hold for all parameter sets, and for all types of agents except for young service providers in the home country. In 1 percent of the cases, they are made worse off in the initial period by a rise in $\beta$, even though both the real interest rate and the relative price of services to food rise. In these cases the inflation rate rises sufficiently to reduce the real rate of return on savings, hurting these agents by more than the rise in relative prices helps them. In the steady state these agents are made worse off by a higher $\beta$ in 25 percent of the cases. In the steady state these agents still benefit from a higher real interest rate. However, now they are hurt not only by a higher inflation rate as in the initial period, but they also are hurt by a fall in the relative price of services to food.

\section{Effects of a Higher $\beta$ (Open-Market Sale)-Small Country Case}

The reasoning about how an increase in $\beta$ affects price variables seems unaffected by scale. And that is largely verified by our results (Table 2). However, the comparative magnitudes of the changes in real rates of return and relative prices do seem likely to be affected by scale. In order to describe scale effects, we consider the steady state. When the home economy is small relative to the rest of the world, the change in its supply of bonds is small relative to the world supply and, hence, is likely to cause only a small change in the real interest rate. However, a given percentage increase in $\beta$ still shrinks the home country's base for the inflation tax as it did before. Thus, the difference in inflation rates between the two countries following a change in $\beta$ is likely to be larger when the home country is small. It follows that the difference in the returns on savings will be larger and that $\mathbf{Q}$ will have to fall more. 
In the steady state we find the relative price transmission channel of monetary policy to be much more important when the economy is small compared to the rest of the world. This can be seen in the welfare effects. For example, an increase in $\beta$ now leads home service-providers to be better off in only 6 percent of the draws, compared to 75 percent in the identical economy case. For them the fall in relative prices becomes more important than the rise in the real interest rate, which is small in these cases. An increase in $\beta$ causes home farmers to be worse off in only 42 percent of the draws, compared to 100 percent in the identical economy case, and again this is explained by a favorable change in relative prices. The welfare effects of a change in $\beta$ in the rest of the world are qualitatively unaffected by scale, since the real interest rate and relative prices abroad move in the same direction and have complementary effects on the welfare of each type of agent.

\section{Effects of a Higher $\lambda$ (Increase in Reserve Requirements)-Large Country Case}

The macroeconomic effects of an increase in the reserve requirement $\lambda$ are much like those of an open-market sale, with the exception of the home country's inflation rate (Figure 6). The similarity between the two is not surprising because both types of monetary policy actions have similar effects on the real interest rate. With a higher $\lambda$ less savings are supplied to the bond market, so that the real interest rate must rise to correspondingly reduce the demand for credit.

In the home country an increase in $\lambda$ tends to lower the inflation rate, but that is the outcome of two opposing effects. One effect is that the resulting higher real interest rate requires the government to raise more seignorage, which tends to cause the inflation rate to rise. However, with a higher $\lambda$ the base for the inflation tax rises, which allows a given amount of seignorage revenue to be raised at a lower inflation rate. In 98 percent of the draws the tax base effect dominates the real interest rate effect, so that the increase in $\lambda$ results in a lower steady-state inflation rate (Table 3). 
An increase in $\lambda$ results in a lower real rate of return on savings in the home country compared to the foreign country. In the foreign country the rise in the real interest rate is quantitatively more important than the rise in the inflation rate, in the sense that the real rate of return on savings rises all the time. In the home country a fall in the inflation rate and rise in real interest rate by themselves cause the real rate of return on savings to rise. However, there is an opposing effect of a higher $\lambda$, since savings are shifted from bonds having a relatively high real rate of return to money having a relatively low rate of return. This shifting effect of a higher $\lambda$ causes the real rate of return on savings to decline in 9 percent of the draws. It also causes the real rate of return on savings in the home country to fall below that in the foreign country all of the time, which, once again, can be considered a transfer of wealth from the home country to the foreign country.

Initial-period wealth transfers from an increase in reserve requirements also are similar to those from an open-market sale. An increase in $\lambda$, like an increase in $\beta$, causes the initial price level in the home country to fall and, consequently, the real wealth of its initial old to rise.

\section{Effects of a Higher $\lambda$ (Increase in Reserve Requirements)-Small Country Case}

Most of the price effects of an increase in $\lambda$ are in the same direction for the small country case as they were for the large country case (Table 4). However, there are some differences. In the small country case the effect of shifting savings from high return bonds to low return money tends to dominate the effect of higher rates of return on both assets, so that the real rate of return on savings tends to decline. It declines in 86 percent of the draws for the small country case, whereas it declined in only 9 percent of the draws for the large country case. The other major difference is, as with the increase in $\beta$, relative price effects are more important when the economy is small. Once again, we can see that with the welfare effects of an increase in $\lambda$ on home country residents. Service providers are made better off in only 6 percent of the draws in the small country 
case, while they were made better off in 75 percent of the draws in the large country case. They are subjected more frequently to a fall in the real rate of return on savings, but they also are affected by a larger fall in the relative price of services to food. That relative price changes are more important in this case is supported by the effects on home country farmers. In the small country case they are made worse off by an increase in $\lambda$ in only 42 percent of the draws, while in the large country case they were made worse off all of the time.

\section{Transition Paths}

The direction and size of wealth redistributions caused by a monetary policy tightening change over time in our model. As in Miller and Wallace (1985), for example, many of the policy impacts we compute change sign between time 1 and the new steady state. Unlike in Miller and Wallace, where the economy jumps to its new steady state after only 1 period, we get a distinct transition period after time 1 during which the economy gradually converges toward the new steady state. This is because the relative price variable in our model acts as a state variable to carry forward the effects of previous wealth shifts. ${ }^{15}$ Many of the effects of a monetary policy change reverse between time 1 and the new steady state, including the effect on real exchange rates. Our model thus offers an alternative to Dornbusch's use of sticky prices and "overshooting" to explain exchange rate reversals.

\section{Summary: The Model's Uses and Limitations}

Although our model is quite specialized, we believe it provides a useful conceptual framework for examining the effects of monetary policy in a world economy. It is a dynamic, general equilibrium model of an open economy with diverse agents, traded and nontraded goods, and separate monetary and budget policies. The channels of monetary policy present in our model are likely to be shared by other models with those characteristics. That is because the effects we found 
seem not to rely as much on our specialized assumptions as on five key features which other models seem likely to share:

1. Traded and nontraded goods,

2. Initial outside nominal debt,

3. Monetarism,

4. Unpleasant monetarist arithmetic, and

5. Restrictions which guarantee that fiat money is held primarily in the country that issues it even though it is dominated in rate of return and even though it could be replaced by other countries' fiat money.

Despite the model's virtues, it has many limitations. There are some obvious ones: no uncertainty, no production, and agents living for just two periods. These obvious limitations suggest obvious extensions to the model.

The demand for money in the model is also very special. Since money demand is proportional to savings, there is no transactions demand for money. If we were to generalize the utility function to make savings interest elastic, then the demand for money in the model would increase when the interest rate increased. One way to correct this problem is to go to a three-period overlapping generations structure with a legal restriction that makes money more liquid than bonds (as in Miller 1982).

The limitations of the model suggest caution in trying to use it to match the data. Nevertheless, we did an empirical exercise to determine whether the policy implications of the model could be quantitatively in the ball park. To do this we attempted to choose parameter values for which the model could give a good account of the experience of the 1980 s. We matched policy parameters to 
actual data as best we could, and we chose deep parameter values to give the most reasonable results (in a sense "estimated" them, see Miller-Todd 1991).

This empirical exercise revealed some potential strengths and weaknesses of the model. The model's implications for price levels and nominal exchange rates in the period following the U.S. monetary tightening in the 1980 s match the data reasonably well. For real interest rates, the monetary tightening can account for about half the rise in U.S. real interest rates if we interpret a time period to be a year. However, we could find no reasonable parameterization under which the model accounts for more than a very small portion of the rise in the U.S. real exchange rate in the early 1980 s.

The failure of the model to explain the magnitude of real exchange rate movements in the 1980s suggests that the model should be modified if it is to be used for quantitative purposes. One possibility is to alter the utility function to make the demands for goods less price elastic. As it is now, the demand for traded goods by service providers is unit elastic with respect to the relative price. Making this demand less elastic would require a bigger change in relative prices to make agents satisfied with the change in consumption of traded goods that is consistent with transfers of wealth.

While this last modification would affect the model's price implications, it is unclear how the modification would change the model's welfare implications. As it is now, small changes in relative prices can result in large changes in welfare. We see that in those cases where welfare is affected more by relative price changes (that are quantitatively small) than by real interest rate changes (that are quantitatively large). It is not clear how differently welfare would be affected by changes in monetary policy when demands are less price elastic. 


\section{Footnotes}

${ }^{1}$ Kimbrough (1987) uses a cash-in-advance constraint to specify a complete general equilibrium model with traded and nontraded goods and independent fiscal and monetary authorities. Although his model seems capable of analyzing the effects of monetary policy, he never solves the model for equilibrium paths under alternative policies and he never considers monetary policy to be open-market operations.

${ }^{2}$ As Wallace (1984) points out, this reserve requirement can be thought of as applying to deposits when all borrowing and lending is intermediated through banks. For the endowment patterns and utility functions we use, it can also be thought of as equivalent to a model in which savers, but not borrowers, are required to hold cash in proportion to either their nominal wealth, nominal income, or their first-period nominal purchases.

${ }^{3}$ The assumption of a world capital market seems consistent with observed interest rate differentials across countries (see Frankel 1989).

${ }^{4}$ Chipman's Theorem 1 implies that, in a static economy similar to ours, a transfer of wealth from the paying country to the receiving country would cause the price of nontraded goods to fall relative to the price of traded goods in the paying country and to rise relative to the price of traded goods in the receiving country. The intuition for this result is simple. Agents in the receiving country wish to consume more of both goods but are only able to consume more of the tradable, which they can import. To reconcile them to this technological fact, the price of nontraded goods must rise in the receiving country. The reverse is true in the paying country, where the decline in wealth makes agents wish to consume less.

${ }^{5}$ Formally, the ratio of the price of the country's nontraded good to its money stock is fixed. ${ }^{6}$ On unpleasant monetarist arithmetic, see Sargent-Wallace 1981. 
${ }^{7} \mathrm{~A}$ change in the real rate of return to savers is also the dominant channel for the transmission of monetary policy effects in Imrohoroglu and Prescott 1991. They assume a reserve requirement in a closed-economy model with infinitely-lived agents.

${ }^{8}$ We have no proof that our perturbed economies converge to a new steady state, but in all cases they appear to do so.

${ }^{9}$ Note that we do not have to apply dynamic programming or other infinite-horizon backward induction methods to solve our infinite horizon model. This property does not hold in many overlapping generations models and would probably disappear here too with more general utility functions and endowment patterns.

${ }^{10}$ For computational efficiencies, we defined $\beta^{\prime} \equiv \mathrm{P}^{\mathrm{B}} \cdot \mathrm{B}^{\mathrm{G}} / \mathrm{H} \equiv \mathrm{B}^{\mathrm{G}} /[(1+\mathrm{r}) \mathrm{H}] \equiv \beta /(1+\mathrm{r})$ and did the experiments with $\beta^{\prime}$ and $\beta^{\prime *}$ as the monetary policy parameters. The parameter $\beta$ is the ratio of the face value of bonds to money, while the parameter $\beta^{\prime}$ is the ratio of the market value of bonds to money. When $\beta$ is fixed and the government's financing requirement changes, it is being assumed that the government must forecast the interest rate to know how much bonds to sell to raise the required revenue. When $\beta^{\prime}$ is fixed, it is being assumed that the government does not have to forecast the interest rate; it just sells all the bonds required to raise the revenue at whatever interest rate it faces. If the conditions for existence and uniqueness of a steady state equilibrium are satisfied for a set of parameters that include $\beta$ and $\beta^{*}$, they will also be satisfied for $\beta^{\prime}$ and $\beta^{\prime *}$, since $\beta^{\prime}<$ $\beta$ and $\beta^{\prime *}<\beta^{*}$ imply that conditions 3 and 4 of Appendix 1 will be satisfied. We found that the steady-state derivatives of the key price variables with respect to a change in monetary policy in the home country were qualitatively the same whether the monetary policy parameter was $\beta$ or $\beta^{\prime}$.

${ }^{11}$ In both the large- and small-country cases discussed below, 505 points were chosen. All points yielded results for the small country $\beta$ experiment. Because of numerical problems in the 
solution algorithm, 3 points in the large country $\beta$ experiment and 5 points in both the large and small country $\lambda$ experiments failed to yield results.

${ }^{12}$ Actually the uniform distribution we use cuts 1 percent away from some boundaries of the set, to avoid violating the boundaries when we increase $\beta$ or $\lambda$ by 1 percent.

${ }^{13}$ Figures 5 and 6 are based on the draw from the parameter space that produced the median response in the real interest rate. Since the two economies are identical, we report the parameter values only for the home country:

$$
\begin{array}{ll}
\delta=0.7499 & \mathbf{g}^{\mathrm{F}}=59.1920 \\
\theta=0.4464 & \mathrm{w}_{1}^{\mathrm{S}}=11,404.5337 \\
\beta=14.1973 & \mathrm{w}_{1}^{\mathrm{P}}=1,016.3155 \\
\lambda=0.0577 & \mathrm{w}_{2}^{\mathrm{F}}=10,000.0000 \\
\mathrm{~g}^{\mathrm{S}}=27.4667 &
\end{array}
$$

${ }^{14}$ Because both types of old agents have identical homothetic preferences, redistributing wealth between them in this way has no effect on aggregate demand or other aggregate variables.

${ }^{15}$ For example, at time 1 the shortfall in home-country prices transfers wealth to the initial old of the home country from future generations in both countries, and this in turn leads to increased aggregate demand, food imports, and a high relative price of services in the home country in period 1. If services are sufficiently valuable at home in time 1 , the real savings of young service providers can rise by enough, relative to the real savings of young foreign service providers whose wealth is being cut by a fall in relative service prices abroad, that in period 2 the then-old home country savers will be wealthier than the then-old savers abroad. This can again lead to food imports and a higherthan-initial-steady-state relative price of services in the home country at time 2 . In less extreme cases, the foreign country will have higher aggregate demand than the home country starting in period 2, but the difference will be less than in the new steady state due to the effect just described. This relative price effect decays each period, however, and is barely noticeable by period 7 . 


\section{Appendix 1:}

\section{Existence and Uniqueness of Steady-State Equilibria}

In this appendix we first express the equilibrium conditions in terms of the basic parameters and price sequences. We then express those conditions for steady states. We conclude with theorems on the existence and uniqueness of steady-state equilibria and sketches of their proofs. In our simulations we restrict parameters to a set in which each point implies the existence of a unique, steady-state equilibrium.

By substituting from equations (2)-(6) and related expressions above, the equilibrium conditions (7)-(11) can be expressed as

For $\mathrm{t}=1$,

(A1a)

$$
\mathrm{w}_{1}^{\mathrm{s}}(1)=\frac{\theta}{1+\delta} \mathrm{w}_{1}^{\mathrm{s}}(1)+\frac{\theta}{\mathrm{Q}(1)} \mathrm{w}_{0}^{\mathrm{F}}(1)+\frac{\theta\left(\mathrm{H}(0)+\mathrm{B}^{\mathrm{G}}(0)\right)}{\mathrm{Q}(1) \mathrm{p}^{\mathrm{F}}(1)}
$$

$$
+\frac{\theta}{1+\delta}\left[\frac{1}{Q(1)}\right]\left[w_{1}^{\mathrm{F}}(1)+\frac{\mathrm{w}_{1}^{\mathrm{F}}(2)}{1+\rho(1)}\right] \mathrm{g}^{\mathrm{s}}(1)
$$

where we have substituted $H(0)+B^{G}(0)$ for $A^{s}-D_{0}$.

For $\mathrm{t} \geq 2$,

$$
\begin{aligned}
\mathrm{w}_{t}^{\mathrm{s}}(\mathrm{t})= & \theta\left[\frac{\delta}{1+\delta}\right]\left[\frac{\mathrm{Q}(\mathrm{t}-1)}{\mathrm{Q}(\mathrm{t})}\right]\left[(1-\lambda(\mathrm{t}-1))(1+\rho(\mathrm{t}-1))+\frac{\lambda(\mathrm{t}-1)}{1+\pi^{\mathrm{F}}(\mathrm{t}-1)}\right] \mathrm{w}_{\mathrm{t}-1}^{\mathrm{s}}(\mathrm{t}-1) \\
& +\frac{\theta}{1+\delta} \mathrm{w}_{t}^{\mathrm{s}}(\mathrm{t})+\theta\left[\frac{\delta}{1+\delta}\right]\left[\frac{1}{\mathrm{Q}(\mathrm{t})}\right](1+\rho(\mathrm{t}-1))\left[\mathrm{w}_{\mathrm{t}-1}^{\mathrm{F}}(\mathrm{t}-1)+\frac{\mathrm{w}_{\mathrm{t}-1}^{\mathrm{P}}(\mathrm{t})}{1+\rho(t-1)}\right] \\
& +\frac{\theta}{1+\delta}\left[\frac{1}{\mathrm{Q}(\mathrm{t})}\right]\left[\mathrm{w}_{\mathrm{t}}^{\mathrm{P}}(\mathrm{t})+\frac{\mathrm{w}_{\mathrm{t}}^{\mathrm{P}}(\mathrm{t}+1)}{1+\rho(t)}\right]+\mathrm{g}^{\mathrm{s}}(\mathrm{t}) .
\end{aligned}
$$

(A2a) and (A2b) are parallel to (1a) and (1b). 
For $\mathrm{t}=1$,

(A3a)

$$
\begin{aligned}
\mathrm{w}_{0}^{\mathrm{P}}(\mathrm{t})+\mathrm{w}_{1}^{\mathrm{P}}(1)+[*]= & {\left[\frac{1-\theta}{1+\delta}\right] \mathrm{Q}(1) \mathrm{w}_{1}^{\mathrm{s}}(1)+(1-\theta) \mathrm{w}_{0}^{\mathrm{P}}(1)+(1-\theta)\left(\mathrm{H}(0)+\mathrm{B}^{\mathrm{G}}(0)\right) / \mathrm{p}^{\mathrm{F}}(1) } \\
& +\left[\frac{1-\theta}{1+\delta}\right]\left[\mathrm{w}_{1}^{\mathrm{P}}(1)+\frac{\mathrm{w}_{1}^{\mathrm{P}}(2)}{1+\rho(1)}\right]+\mathrm{g}^{\mathrm{F}}(1)+[*],
\end{aligned}
$$

where [*] repeats all expressions on its side of the equation but substitutes corresponding terms for the foreign country.

For $\mathrm{t} \geq 2$,

$$
\begin{aligned}
\mathrm{w}_{t-1}^{\mathrm{F}}(\mathrm{t}) & +\mathrm{w}_{t}^{\mathrm{P}}(\mathrm{t})+[*] \\
= & {\left[\frac{(1-\theta) \delta}{1+\delta}\right]\left[\frac{\mathrm{Q}(\mathrm{t}-1)}{\mathrm{Q}(\mathrm{t})}\right]\left[(1-\lambda(t-1))(1+\rho(t-1))+\frac{\lambda(t-1)}{1+\pi^{\mathrm{P}}(\mathrm{t}-1)}\right] \mathrm{Q}(\mathrm{t}) \mathrm{w}_{\mathrm{t}-1}^{\mathrm{s}}(\mathrm{t}-1) } \\
& +\left[\frac{1-\theta}{1+\delta}\right] \mathrm{Q}(\mathrm{t}) \mathrm{w}_{t}^{\mathrm{s}}(\mathrm{t})+\left[\frac{(1-\theta) \delta}{1+\delta}\right](1+\rho(\mathrm{t}-1))\left[\mathrm{w}_{\mathrm{t}-1}^{\mathrm{P}}(\mathrm{t}-1)+\frac{\mathrm{w}_{\mathrm{t}-1}^{\mathrm{P}}(\mathrm{t})}{1+\rho(\mathrm{t}-1)}\right] \\
& +\left[\frac{1-\theta}{1+\delta}\right]\left[\mathrm{w}_{\mathrm{t}}^{\mathrm{P}}(\mathrm{t})+\frac{\mathrm{w}_{t}^{\mathrm{P}}(\mathrm{t}+1)}{1+\rho(t)}\right]+\mathbf{g}^{\mathrm{F}}(\mathrm{t})+[*] .
\end{aligned}
$$

(A3b)

For $\mathrm{t}=1$

(A4a)

$$
\begin{aligned}
\mathrm{Q}(1) \mathrm{g}^{\mathrm{s}}(1)+\mathrm{g}^{\mathrm{F}}(1)= & \lambda(1) \mathrm{Q}(1)\left[\frac{\delta}{1+\delta}\right] \mathrm{w}_{1}^{\mathrm{s}}(1)\left[1+\frac{\beta(1)}{(1+\rho(1))\left(1+\pi^{P}(1)\right)}\right] \\
& -\left[\frac{\mathrm{H}(0)+\mathrm{B}^{\mathrm{G}}(0)}{\mathrm{p}^{\mathrm{P}}(1)}\right]
\end{aligned}
$$

where use has been made of the government's budget constraint to write equation (10) in terms of the parameters and basic price sequences. 
For $\mathrm{t} \geq 2$,

$$
\begin{aligned}
Q(t) g^{s}(t)+g^{F}(t)= & \lambda(t) Q(t)\left[\frac{\delta}{1+\delta}\right] w_{t}^{s}(t)\left[1+\frac{\beta(t)}{(1+\rho(t))\left(1+\pi^{F}(t)\right)}\right] \\
& -\lambda(t-1) Q(t-1)\left[\frac{\delta}{1+\delta}\right] w_{t-1}^{s}(t-1)\left[\frac{1+\beta(t-1)}{1+\pi^{F}(t-1)}\right]
\end{aligned}
$$

(A5a) and (A5b) are parallel to (A4a) and (A4b).

We refer to the old at time 1 as generation 0 and define $p(t)=\left[p^{s}(t) p^{F}(t)\right]$ and $g(t)=\left[g^{s}(t)\right.$ $\left.\mathrm{g}^{\mathrm{F}}(\mathrm{t})\right]$. Then, given initial values $\left[\mathrm{H}(0)+\mathrm{B}^{\mathrm{G}}(0)\right]$ and $\left[\mathrm{H}^{*}(0)+\mathrm{B}^{\mathrm{G}^{*}}(0)\right]$, preference parameters $\delta$ and $\theta$, and $t \geq 1$ time paths for endowments and policy parameters $\left(\mathrm{g}(\mathrm{t}), \mathrm{g}^{*}(\mathrm{t}), \lambda(\mathrm{t}), \lambda^{*}(\mathrm{t}), \beta(\mathrm{t}), \beta^{*}(\mathrm{t})\right)$, an equilibrium is a set of initial prices $p(1), p^{*}(1)$ plus the $t \geq 1$ price sequences $\rho(t), Q(t), Q^{*}(t)$, $\pi^{\mathrm{F}}(t)$, and $\pi^{\mathrm{P} *}(\mathrm{t})$ such that equations (A1a)-(A5a) are satisfied at $t=1$ and (A1b)-(A5b) are satisfied

for $t \geq 2$. By construction, all markets clear at these prices, the governments' budget constraints are satisfied, and individuals maximize utility subject to their budget constraints.

Initial values are needed to determine nominal price levels. The key initial value for each country is the total amount of outside government debt (money and bonds).

\section{Steady-States}

Steady-states are defined for particular stationary endowment patterns and policies. Steadystate endowment patterns are of the form $w_{t}(t)=w_{1}$ and $w_{t}(t+1)=w_{2}$ for $t \geq 1$. Thus, service providers of any generation are endowed with $w_{1}^{s}$ of services when young and 0 when old. Similarly, farmers of any generation are endowed with $w_{1}^{P}$ of food when young and $w_{2}^{P}>w_{1}^{p}$ when old. Parallel endowment patterns hold in the foreign country.

Steady-state policies are of the form $\mathrm{g}(\mathrm{t}) \equiv\left(\mathrm{g}^{\mathrm{S}}(\mathrm{t}), \mathrm{g}^{\mathrm{F}}(\mathrm{t})\right)=\left(\mathrm{g}^{\mathrm{s}}, \mathrm{g}^{\mathrm{F}}\right), \lambda(\mathrm{t})=\lambda$, and $\beta(\mathrm{t})=\beta$ for $t=1,2, \ldots$, and similarly for the foreign country. Thus, steady-state policies have, in each 
period, the same government consumption of each good, the same reserve requirement, and the same ratio of government bonds to money.

We define a steady-state as a solution of (A1b)-(A5b) for steady-state endowments and policies such that $\rho(t)=\rho, Q(t)=Q, Q^{*}(t)=Q^{*}, \pi^{F}(t)=\pi^{F}$ and $\pi^{F^{*}}(t)=\pi^{p *}$ for $t \geq 2$. A steady-state is then a solution to the following steady-state versions of (A1b)-(A5b):

(A1ss) $\begin{aligned}\{\delta & {\left.\left[(1-\lambda)(1+\rho)+\frac{\lambda}{1+\pi^{\mathrm{P}}}\right]+\left[1-\left[\frac{1+\delta}{\theta}\right]\right]\right\} \mathrm{Q} \mathrm{w}_{1}^{\mathrm{s}} } \\ & +[1+\delta(1+\rho)] \mathrm{w}_{1}^{\mathrm{P}}+\left[\frac{1+\delta(1+\rho)}{1+\rho}\right] \mathrm{w}_{2}^{\mathrm{P}}+\left[\frac{1+\delta}{\theta}\right] \mathrm{Qg}^{\mathrm{s}}=0 .\end{aligned}$

(A2ss) is parallel to (A1ss).

(A3ss)

$$
\begin{gathered}
\left\{1+\delta\left[(1-\lambda)(1+\rho)+\frac{\lambda}{1+\pi^{\mathrm{F}}}\right]\right\} \mathrm{Qw}_{1}^{\mathrm{S}}+\left[\delta(1+\rho)-\left[\frac{\theta+\delta}{1-\theta}\right]\right] \mathrm{w}_{1}^{\mathrm{P}} \\
+\left[\frac{1}{1+\rho}-\left[\frac{1+\delta \theta}{1-\theta}\right]\right] \mathrm{w}_{2}^{\mathrm{P}}+\left[\frac{1+\delta}{1-\theta}\right] \mathrm{g}^{\mathrm{F}}+[*]=0,
\end{gathered}
$$

where $\left[{ }^{*}\right]$ means repeat all terms but substitute foreign country variables.

(A4ss) $\left[\frac{\lambda \delta}{1+\delta}\right]\left[\frac{\pi^{F}}{1+\pi^{F}}-\frac{\beta \rho}{(1+\rho)\left(1+\pi^{F}\right)}\right]{Q w_{1}^{s}}^{s} Q^{s}-g^{F}=0$.

(A5ss) is parallel to (4ss).

If there is a solution to (A1ss)-(A5ss), then initial values can be chosen for $\mathrm{H}(0)+\mathrm{B}^{\mathrm{G}}(0)$ and $\mathrm{H}^{*}(0)+\mathrm{B}^{\mathrm{G}^{*}}(0)$ so that the solution also satisfies (A1a)-(A5a); that is, the steady-state solution $\rho_{0}, \mathrm{Q}_{0}, \mathrm{Q}_{0}^{*}, \pi_{0}^{\mathrm{F}}, \pi_{0}^{\mathrm{F} *}$ is also a solution at $\mathrm{t}=1$. To show this, we note that if $\rho_{0}, \mathrm{Q}_{0}, \mathrm{Q}_{0}^{*}, \pi_{0}^{\mathrm{F}}, \pi_{0}^{\mathrm{F} *}$ is a solution to (A1ss)-(A5ss), it is also a solution to (1a)-(5a) when the initial values in each country are 


$$
\begin{aligned}
\frac{\mathrm{H}(0)+\mathrm{B}^{\mathrm{G}}(0)}{\mathrm{p}^{\mathrm{P}}(1)}= & {\left[\frac{\delta}{1+\delta}\right]\left[(1-\lambda)\left(1+\rho_{0}\right)+\frac{\lambda}{1+\pi_{0}^{\mathrm{F}}}\right] \mathrm{Q}_{0} \mathrm{w}_{1}^{\mathrm{s}} } \\
& +\left[\frac{\delta}{1+\delta}\right]\left(1+\rho_{0}\right) \mathrm{w}_{1}^{\mathrm{P}}-\left[\frac{1}{1+\delta}\right] \mathrm{w}_{2}^{\mathrm{P}} \\
\frac{\mathrm{H}^{*}(0)+\mathrm{B}^{\mathrm{G} *}(0)}{\mathrm{p}^{\mathrm{F}}(1)} & =\text { same as above with } * \text { variables. }
\end{aligned}
$$

We now state sufficient conditions for the existence and uniqueness of solutions to (A1ss)-(A5ss). We consider solutions for which $\rho>0$ to ensure that the reserve requirement is binding. Let $\gamma$ be a vector of parameter values: preferences, endowments, and policies. We are able to rewrite (A1ss)-(A5ss) in the form:

$$
\begin{aligned}
& \mathrm{E}(\rho ; \gamma)=0, \\
& \mathrm{Q}=\psi(\rho ; \gamma), \\
& \mathrm{Q}^{*}=\psi^{*}(\rho ; \gamma), \\
& \pi^{\mathrm{F}}=\phi(\rho, \mathrm{Q} ; \gamma) \text {, and } \\
& \pi^{\mathrm{P}}=\phi^{*}\left(\rho, \mathrm{Q}^{*} ; \gamma\right), \text { where the functions } \psi, \psi^{*}, \phi, \text { and } \phi^{*} \text { map into } \mathbf{R}_{+}, \mathbf{R}_{+}, \mathbf{R} \text {, and } \mathbf{R}, \\
& \text { respectively. }
\end{aligned}
$$

Thus, to show existence and uniqueness for the system, we need only show it for the first equation, $\mathrm{E}(\rho ; \gamma)=0$. We state our theorems and provide sketches of the proofs. Detailed proofs are available from the authors.

We first define feasible budget policies as elements of the set of nonnegative government consumption bundles that can be financed at a zero real interest rate and infinite inflation rate. (We can use zero interest and infinite inflation to define this set because savers in our model save a constant fraction of their wealth, independent of rate of return. Thus there is no Laffer curve, and government seignorage is everywhere increasing in inflation and decreasing in $\rho$. See Equation 
A4ss.) For the home country, that is, feasible budget policies $\mathrm{g}^{\mathrm{S}}$ and $\mathrm{g}^{\mathrm{p}}$ must be individually nonnegative and satisfy the following budget constraint for $\rho=0$ and $\pi^{\mathrm{F}}$ as $\pi^{\mathrm{P}} \rightarrow \infty$ :

$$
0<\psi(0 ; \gamma) g^{S}+g^{F} \leq \lambda\left[\frac{\delta}{1+\delta}\right] \psi(0 ; \gamma) w_{1}^{S},
$$

where

$$
\psi(0 ; \gamma) \equiv \mathrm{Q}(\text { given } \rho=0)=\frac{\theta}{1-\theta}\left[\frac{\mathrm{w}_{1}^{\mathrm{P}}+\mathrm{w}_{2}^{\mathrm{P}}-\mathrm{g}^{\mathrm{P}}}{\mathrm{w}_{1}^{\mathrm{S}}-\mathrm{g}^{\mathrm{S}}}\right] .
$$

Theorem (Existence). For all feasible budget policies, a positive real interest rate equilibrium exists if

1. $5 / 8<\delta<1$

2. $\delta \leq(1-\theta) / \theta<1+\delta$

3. $\lambda<1 /(1+\beta)$

4. $\lambda^{*}<1 /\left(1+\beta^{*}\right)$

5. $\mathrm{w}_{2}^{\mathrm{P}}>\mathrm{kw}_{1}^{\mathrm{P}}$

6. $\mathrm{w}_{2}^{\mathrm{p}}>\mathrm{k}^{*} \mathrm{w}_{1}^{\mathrm{F} *}$

where

$$
-\mathrm{k} \equiv\left[\frac{\delta(1-\lambda) /(1+\delta(1-\lambda)) \mathrm{b}+\delta /(1+\delta)}{\delta(1-\lambda) /(1+\delta(1-\lambda)) \mathrm{b})-1 /(1+\delta)}\right]<0
$$

and $\mathrm{k}^{*}$ is defined similarly.

Proof. The proof has three parts. We show that given feasible budget policies and conditions 1-6
A. $\mathrm{E}(0 ; \gamma)<0$,
B. $E(\rho ; \gamma)$ is continuous with respect to $\rho$ for $0 \leq \rho<\rho_{\mathrm{c}}<1$, and
C. $\mathrm{E}(\rho ; \gamma) \rightarrow \infty$ as $\rho \rightarrow \rho_{\mathrm{c}}$. 
In order to gain some economic intuition for our conditions, it helps to think why an equilibrium with a positive interest rate may not exist in this model. There seem to be three possibilities. First, the government could consume more than it can raise in seignorage. We rule out this possibility by restricting budget policies to a set that is feasible at zero real interest rates and then by bounding $\delta$ and $\theta$ away from zero (left side of condition 1 and right side of condition 2) so that demand for credit does not drive interest rates too far from zero. Second, the demand for loans could be less than the supply of loans at a zero real interest rate. To prevent this possibility, farmers need a second-period endowment sufficiently greater than their first-period endowment (conditions 5 and 6) to make them want to borrow enough. Farmers also must be impatient enough (right side of condition 1) to want to borrow, while service providers must be relatively poor enough (left side of condition 2) to make them not want to lend too much. Third, if high reserve requirements force a large fraction of real savings to be held in the form of money, the remaining portion of real savings may be less than or equal to the real amount of bonds the government wishes to issue. Since this would drive out private bonds, we rule it out by making the reserve requirement sufficiently small relative to the money portion of total government debt (conditions 3 and 4).

In order to state our uniqueness theorem we first make some definitions. Let

$$
\begin{aligned}
& \omega \equiv\left\langle\mathrm{w}_{1}^{\mathrm{S}}, \mathrm{w}_{1}^{\mathrm{P}}, \mathrm{w}_{2}^{\mathrm{P}}, \mathrm{g}^{\mathrm{S}}, \mathrm{g}^{\mathrm{F}}\right\rangle, \text { similarly for } \omega^{*}, \text { and } \\
& \left\langle\kappa, \omega, \kappa^{*}, \omega^{*}\right\rangle \equiv \gamma, \text { a partition of parameters according to country. }
\end{aligned}
$$

Theorem (Uniqueness). For all feasible budget policies there exists exactly one equilibrium with a positive real interest rate if

A. Conditions 1, 2, 5, and 6 of the previous theorem are satisfied,

B. Conditions 3 and 4 of the previous theorem are modified to

$3^{\prime} . \lambda<\min \{1 / 3,1 /(1+\beta)\}$ 


$$
\begin{array}{r}
4^{\prime} . \lambda^{*}<\min \left\{1 / 3,1 /\left(1+\beta^{*}\right)\right\}, \\
\text { C. } \kappa=\kappa^{*} \text { and } \omega=z \omega^{*} \text { for } \mathrm{z} \gg 0 \text {. }
\end{array}
$$

The theorem basically states that when a positive real interest rate equilibrium exists, it will be unique if the only difference in the two economies is one of scale.

Proof. We show that $\mathrm{E}(\rho ; \gamma)$ can be written:

$$
\begin{aligned}
\mathrm{E}(\rho ; \gamma)= & \mathrm{H}(\rho ; \kappa, \omega)\left[\mathrm{K}_{3}(\kappa, \omega) \rho^{3}+\mathrm{K}_{2}(\kappa, \omega) \rho^{2}+\mathrm{K}_{1}(\kappa, \omega) \rho+\mathrm{K}_{0}(\kappa, \omega)\right] \\
& +\mathrm{H}\left(\rho ; \kappa^{*}, \omega^{*}\right)\left[\mathrm{K}_{3}\left(\kappa^{*}, \omega^{*}\right) \rho^{3}+\mathrm{K}_{2}\left(\kappa^{*}, \omega^{*}\right) \rho^{2}+\mathrm{K}_{1}\left(\kappa^{*}, \omega^{*}\right) \rho+\mathrm{K}_{0}\left(\kappa^{*}, \omega^{*}\right)\right] .
\end{aligned}
$$

If the conditions of the theorem are satisfied, the functions $\mathrm{H}$ and $\mathrm{K}_{\mathrm{i}}$ have the properties

1. $\mathrm{H}>0$ for $0 \leq \rho<\rho_{\mathrm{c}}$,

2. $\mathrm{K}_{3}>0$ and $\mathrm{K}_{0}<0$,

3. $\mathrm{H}(\rho ; \kappa, z \omega)=\mathrm{zH}(\rho ; \kappa ; \omega)$, and

4. $\mathrm{K}_{\mathrm{i}}(\kappa, \mathrm{z} \omega)=\mathrm{z}^{2} \mathrm{~K}_{\mathrm{i}}(\kappa, \omega)$.

We first show that for given parameters the cubic in $\rho$ given by $\mathrm{K}_{3} \rho^{3}+\mathrm{K}_{2} \rho^{2}+\mathrm{K}_{1} \rho+\mathrm{K}_{0}$ has a single positive root. By 2 above $K_{3}>0$ and $K_{0}<0$. It then follows that if $K_{2} \geqq 0$ or $K_{1} \leqq 0$ the cubic expression has a single positive root. Suppose instead that $K_{2}<0$ and $K_{1}>0$. The cubic then has positive slope at $\rho=0$, where the slope is simply $3 \mathrm{~K}_{3} \rho^{2}+2 \mathrm{~K}_{2} \rho+\mathrm{K}_{1}$. The slope does not change sign with respect to $\rho$ if $\mathrm{K}_{2}^{2}-3 \mathrm{~K}_{1} \mathrm{~K}_{3}<0$. With $\mathrm{K}_{3}>0, \mathrm{~K}_{2}<0$, and $\mathrm{K}_{1}>0$ the slope is positive for all $\rho$ if there exists an $x>0$ such that $x_{1}+K_{2}>0$ and $(3 / x) K_{3}+$ $K_{2}>0$. We show that the last two inequalities hold with $x=1$.

We next observe that by 1 the expression $\mathrm{H}\left(\mathrm{K}_{3} \rho^{3}+\mathrm{K}_{2} \rho^{2}+\mathrm{K}_{1} \rho+\mathrm{K}_{0}\right)$ has a single positive root. This implies that if the countries are identical there is a unique positive real interest rate equilibrium. 
We now show that when condition $\mathrm{C}$ of the theorem holds there is a unique positive real interest rate equilibrium. So, suppose $\kappa=\kappa^{*}$ and $\omega=z \omega^{*}$. Then, by 3 and $4, E(\rho ; \gamma)=$ $\left(1+z^{3}\right) H\left(K_{3} \rho^{3}+K_{2} \rho^{2}+K_{1} \rho+K_{0}\right)$, which has a single positive root. Note the equilibrium for the two economies differing only by the scale factor $\mathrm{z}$ is the same as that for two identical economies with size $\omega^{\prime}=\left(\left(1+z^{3}\right) / 2\right) \omega$. 


\section{Appendix 2:}

\section{An Equivalent Nonmonetary Economy}

We will propose a nonmonetary economy and show that its taxes and transfers can be set in such a way that the equilibrium relative prices and real interest rates of the monetary model will also be equilibrium prices and interest rates in the nonmonetary economy, and that the consumption allocations of the two equilibria are identical.

Let the nonmonetary economy be identical to the monetary economy except that neither government issues money or bonds but rather each imposes on its own residents only, lump-sum taxes and transfers and an excise tax on intertemporal purchases, payable by the purchaser upon delivery. It will be enough, for now, to (a) let $\tau_{t}^{s}(t)$ and $\tau_{t}^{s}(t+1)$ be first- and second-period (respectively) lump-sum real taxes or transfers imposed on service providers, (b) let $\tau_{0}^{P}(1)$ be a lumpsum real tax on the initial old farmers, and (c) let $\alpha(t+1)$ be the ad valorem rate of the time $t+1$ excise tax on time $t$ private contracts calling for delivery of goods at $t+1$. Both the home and foreign governments possess these instruments, but we will only analyze the home country since the foreign country's situation is parallel.

We will now argue that these taxes can be set so that when consumers in the nonmonetary economy are faced with the relative prices and real interest rates of the monetary economy, the relevant portions of their budgets sets are the same as in the monetary economy. This will imply that they will optimize by choosing the same consumption bundle as in the monetary economy, and this in turn will imply that markets still clear (since by assumption there is no change in government consumption). We then complete the proof of equivalence by pointing out that the government's budget constraint is also satisfied. 
The fact that service providers may now receive a transfer in the second period of life raises the possibility that they may wish to borrow rather than lend when young. For now, we will assume that is not the case, and later we will show that this assumption is warranted. Given that young service providers born at time 1 or later are still net lenders when young, their budget constraint in the nonmonetary economy becomes

$$
\begin{aligned}
& \bar{Q}(t) w^{S}(t)-\bar{\tau}_{t}^{S}(t)-\bar{\tau}_{t}^{S}(t+1) /[1+\bar{\rho}(t)] \\
& =\bar{Q}(t) \bar{c}_{t: S}^{S}(t)+\bar{c}_{t: S}^{\mathrm{P}}(t)+\left[\bar{Q}(t+1) \bar{c}_{t: S}^{S}(t+1)+\bar{c}_{t: S}^{\mathrm{P}}(t+1)\right] /[(1+\bar{\rho}(t)) /(1+\bar{\alpha}(t+1))],
\end{aligned}
$$

where overbars indicate variables whose values are specific to the nonmonetary economy and variables without overbars take values that are either common to the two economies or specific to the monetary economy. Note that the young service providers discount second-period wealth differently than second-period consumption because the excise tax falls on the latter but not the former.

At time 1, the budget constraint of old service providers becomes

$$
\bar{b}^{\mathrm{P}}(1)-\bar{\tau}_{0}^{\mathrm{S}}(1)=\overline{\mathrm{Q}}(1) \overline{\mathrm{c}}_{0: \mathrm{S}}^{\mathrm{S}}(1)+\overline{\mathrm{c}}_{0: \mathrm{S}}^{\mathrm{P}}
$$

where $\bar{b}^{\mathrm{P}}(1)$ indicates the real value of the private debt owed to initial old service providers by initial old farmers. Note that the excise tax is not imposed on the initial old.

Assuming, as will turn out to be the case, that young farmers born at time 1 or later remain net borrowers, their budget constraint is algebraically unchanged, since they neither pay taxes in the nonmonetary economy nor hold money or bonds in the monetary economy. At time 1, the budget constraint of the initial old farmers becomes

$$
\mathbf{w}_{0}^{\mathrm{F}}(1)-\bar{b}^{\mathrm{P}}(1)-\bar{\tau}_{0}^{\mathrm{P}}(1)=\overline{\mathrm{Q}}(1) \overline{\mathrm{c}}_{0: \mathrm{F}}^{\mathrm{S}}+\overline{\mathrm{c}}_{0: \mathrm{P}}^{\mathrm{P}}
$$


The government's budget constraint is also modified. At time $t=2$ and later it becomes

$$
\bar{Q}(t) g^{S}(t)+g^{F}(t)=\bar{\tau}_{t}^{S}(t)+\bar{\tau}_{t-1}^{S}(t)+\bar{\alpha}(t)\left[\bar{Q}(t) \bar{c}_{t-1: s}^{S}(t)+\bar{c}_{t-1: S}^{P}(t)\right]
$$

At time $\mathrm{t}=1$ it becomes

$$
\overline{\mathrm{Q}}(\mathrm{t}) \mathrm{g}^{\mathrm{S}}(1)+\mathrm{g}^{\mathrm{F}}(1)=\bar{\tau}_{1}^{\mathrm{S}}(1)+\bar{\tau}_{0}^{\mathrm{S}}(1)+\bar{\tau}_{0}^{\mathrm{P}}(1)
$$

We now set taxes so that at the prices and interest rates of the monetary economy the consumer budget constraints of the nonmonetary economy are equivalent to those in the monetary economy. For this to be true for service providers born at time $t=1$ or later, we must have that their pattern of taxes and transfers preserves the present value of their wealth and that the excise tax preserves their intertemporal terms of trade. To meet these conditions, set, for $t=1$ or later,

$$
\begin{aligned}
& \bar{\tau}_{t}^{S}(t)=\left[B^{G}(t) /(1+r(t))+H(t)\right] / p^{F}(t) \\
& \bar{\tau}_{t}^{S}(t+1)=-\left[B^{G}(t)+H(t)(1+r(t))\right] / p^{F}(t+1) \\
& \bar{\alpha}(t+1)=\lambda(t) r(t) /[1+(1-\lambda(t)) r(t)] .
\end{aligned}
$$

Note that the variables on the right side of the equal signs take on their equilibrium values from the monetary economy. The logic behind these expressions is for taxes to reproduce in the nonmonetary economy the same exchanges of resources between service producers and the government that occur in the monetary economy. Thus the lump-sum tax on young service producers equals, in real terms, the amount of government bonds and money purchased by young service providers in the monetary economy. The lump-sum transfer to old service producers equals the gross return that young service providers in the monetary economy would get on their holdings of government assets if the return on money equaled the return on bonds, and the excise tax is set to offset this gross return by just the amount that service producers "lose" on their money holdings in the monetary economy. 
A similar rationale underlies the time 1 transfer to the initial old service producers. It is set to equal their gross return on government assets in the monetary model, plus a transfer that can be set equal to "capital gains" on private debt in the case of unanticipated policy shifts at time 1 , or

$$
\bar{\tau}_{0}^{S}(t)=-\left[B^{G}(0) H(0)\right] / p^{P}(1)-\bar{\tau}_{0}^{F}(1)
$$

The setting of $\bar{\tau}_{0}^{\mathrm{F}}$, which represents the capital gains/losses of initial old service providers and the capital losses/gains of initial old farmers on their private debt when a time 1 policy change causes an unanticipated change in the time 1 price level, depends on the definition of $\bar{b}^{\mathrm{p}}(1)$, the real value of this debt. We can either set $\bar{b}^{\mathrm{P}}(1)=\mathrm{D}_{0} / \mathrm{p}_{\mathrm{e}}^{\mathrm{F}}(1)$ or $\overline{\mathrm{b}}^{\mathrm{P}}(1)=\mathrm{D}_{0} / \mathrm{P}^{\mathrm{P}}(1)$, where $\mathrm{p}_{\mathrm{e}}^{\mathrm{P}}(1)$ is the anticipated time 1 food price and $\mathrm{p}^{\mathrm{F}}(1)$ is the actual time 1 food price in the monetary equilibrium. In the latter case, we set $\bar{\tau}_{0}^{\mathrm{F}}(1)=0$, and in the former case we set it equal to $\mathrm{D}_{0} / \mathrm{p}^{\mathrm{F}}(1)-\mathrm{D}_{0} / \mathrm{p}_{0}^{\mathrm{F}}(1)$. Inspection of the time 1 budget constraints shows that the two approaches are interchangeable.

We claim that, with taxes defined as indicated above, the equilibrium prices and interest rates of the monetary economy give rise to an equilibrium in the nonmonetary economy whose consumption allocation is identical to the allocation in the monetary economy. To see this, substitute taxes from above and prices and interest rates from the monetary equilibrium into the budget constraints of the nonmonetary economy. Noticing that when $\bar{\rho}(\mathrm{t})=\rho(\mathrm{t})$ we get $[(1+\bar{\rho}(\mathrm{t})) /(1+\bar{\alpha}(\mathrm{t}+1))]=$ $1+\rho_{s}(t)$, it is easily shown that exactly the same bundles available in the monetary economy are also available in the nonmonetary economy, except in cases where young service providers would wish to borrow (consume in the first period more than their after-lump-sum-tax first period endowment). In that direction, the budget set in the nonmonetary economy lies strictly inside the budget set in the monetary economy. However, this region is irrelevant, for if young service providers did not prefer a point on the frontier of this region in the monetary economy, they will surely not prefer a point on its more restrictive frontier in the nonmonetary economy, since the same alternative 
bundles are still available. Another way to say it is that since lump-sum taxes on young service providers equal only a portion of what they chose to save in the nonmonetary economy (namely the portion of their savings they allocated to government bonds), and since their return on savings and after-tax second-period wealth are the same, they will still be net savers in the nonmonetary economy.

Since the relevant portions of all consumer budget lines are equivalent, consumers will optimize subject to these constraints by choosing the same consumption bundles as before. Hence markets again clear. Finally, equating consumptions as well as prices and interest rates between the nonmonetary and monetary economies and substituting for taxes in the government budget constraint shows that it too is satisfied. (The key is to substitute $\left[\mathrm{B}^{\mathrm{G}}(\mathrm{t}) /(1+\mathrm{r}(\mathrm{t}))+\mathrm{H}(\mathrm{t})-\mathrm{H}(\mathrm{t}-1)-\right.$ $\left.B^{G}(t-1)\right] / p^{F}(t)$ for $Q(t) g^{S}(t)+g^{F}(t)$ in the government budget constraint and then to recognize that $H(t-1)=\lambda(t-1) p^{F}(t-1)\left[Q(t) c_{t-1: s}^{S}(t)+c_{t-1: s}^{F}(t)\right] /\left(1+\rho_{s}(t-1)\right)$.) This completes the proof that a particular equivalent nonmonetary equilibrium exists.

It is now easy to show that in fact a continuum of equivalent nonmonetary equilibria exist. For example, suppose that we change the nonmonetary economy above by levying a lump-sum tax on young farmers at time $t$, the proceeds being transferred to young service providers, and then by reducing the lump-sum transfer to old service producers at time $t+1$ by enough to transfer to old farmers $(1+\rho(t))$ times the tax they paid when young. This scheme leaves all agents' budget constraints and intertemporal terms of trade as in the original nonmonetary equilibrium and obviously has no effect on the government's budget constraint.

Note that reproducing our policy experiments in the nonmonetary economy requires tax changes in both countries. That is, a unilateral tightening of monetary policy by the home country in the monetary model is equivalent, in the nonmonetary economy, to a package of home and foreign country tax changes. (However, it does not require either government to tax or transfer to citizens 
of the other country.) This equivalence in these models of unilateral monetary policy changes and multilateral tax changes highlights the potential for international disputes over monetary policy (see Miller and Wallace 1985). 


\section{References}

Aizenman, Joshua. 1983. A theory of current account and exchange rate determinations. European Economic Review 23: 261-80.

Auerbach, Alan J., and Kotlikoff, Laurence J. 1987. Dynamic fiscal policy. Cambridge, MA: Cambridge University Press.

Blanchard, O. J. 1984. The Lucas critique and the Volcker deflation. American Economic Association Papers and Proceedings 74: 211-15.

Chipman, John S. 1974. The transfer problem once again. In Trade, Stability, and Macroeconomics: Essays in Honor of Lloyd A. Metzler, ed. George Horwich and Paul A. Samuelson. New York: Academic Press.

Dornbusch, Rudiger. 1976. Expectations and exchange rate dynamics. Journal of Political Economy 84: 1161-76.

Frankel, Jeffrey A. 1986. Expectations and commodity price dynamics: The overshooting model. American Journal of Agricultural Economics 68: 344-48.

1989. International financial integration, relations among interest rates and exchange rates, and monetary indicators. In International financial integration and U.S. monetary policy, ed. C. Pigott, New York: Federal Reserve Bank of New York.

Frenkel, Jacob A., and Razin, Assaf. 1987. Fiscal policies and the world economy: An intertemporal approach. Cambridge, MA: The MIT Press.

Greenwood, Jeremy P. 1984. Non-traded goods, the trade balance, and the balance of payments. Canadian Journal of Economics 17: 806-23. 
İmrohoroglu, Ayşe, and Prescott, Edward C. 1991. Evaluating the welfare effects of alternative monetary arrangements. Federal Reserve Bank of Minneapolis Quarterly Review, Summer: 3-10.

Kimbrough, Kent P. 1987. International linkages, exchange-rate regimes, and the international transmission process: Perspectives from optimizing models. In International Economics, ed. Lawrence H. Officer. Boston: Kluwer Academic Publishers.

Miller, Preston J. 1982. Fiscal policy in a monetarist model. Research Department Staff Report 67, Federal Reserve Bank of Minneapolis.

Miller, Preston J., and Roberds, W. 1991. The quantitative significance of the Lucas critique. Journal of Business and Economic Statistics 9: 361-87.

Miller, Preston J., and Todd, Richard M. 1991. Monetary policy transmission when there are nontraded goods. Research Department Working Paper 481, Federal Reserve Bank of Minneapolis.

Miller, Preston J., and Wallace, Neil. 1985. International coordination of macroeconomic policies: A welfare analysis. Federal Reserve Bank of Minneapolis Quarterly Review 9: 14-32.

Orden, David. 1986. A critique of exchange rate treatment in agriculture trade models: Comment. American Journal of Agricultural Economics 68: 990-93.

Rotemberg, J. J. 1985. Money and the terms of trade. Journal of International Economics 19: $141-60$.

Sargent, Thomas J., and Wallace, Neil. 1981. Some unpleasant monetarist arithmetic. Federal Reserve Bank of Minneapolis Quarterly Review 5: 1-17.

Wallace, N. 1984. Some choices for monetary policy. Federal Reserve Bank of Minneapolis Quarterly Review 8: 15-24. 


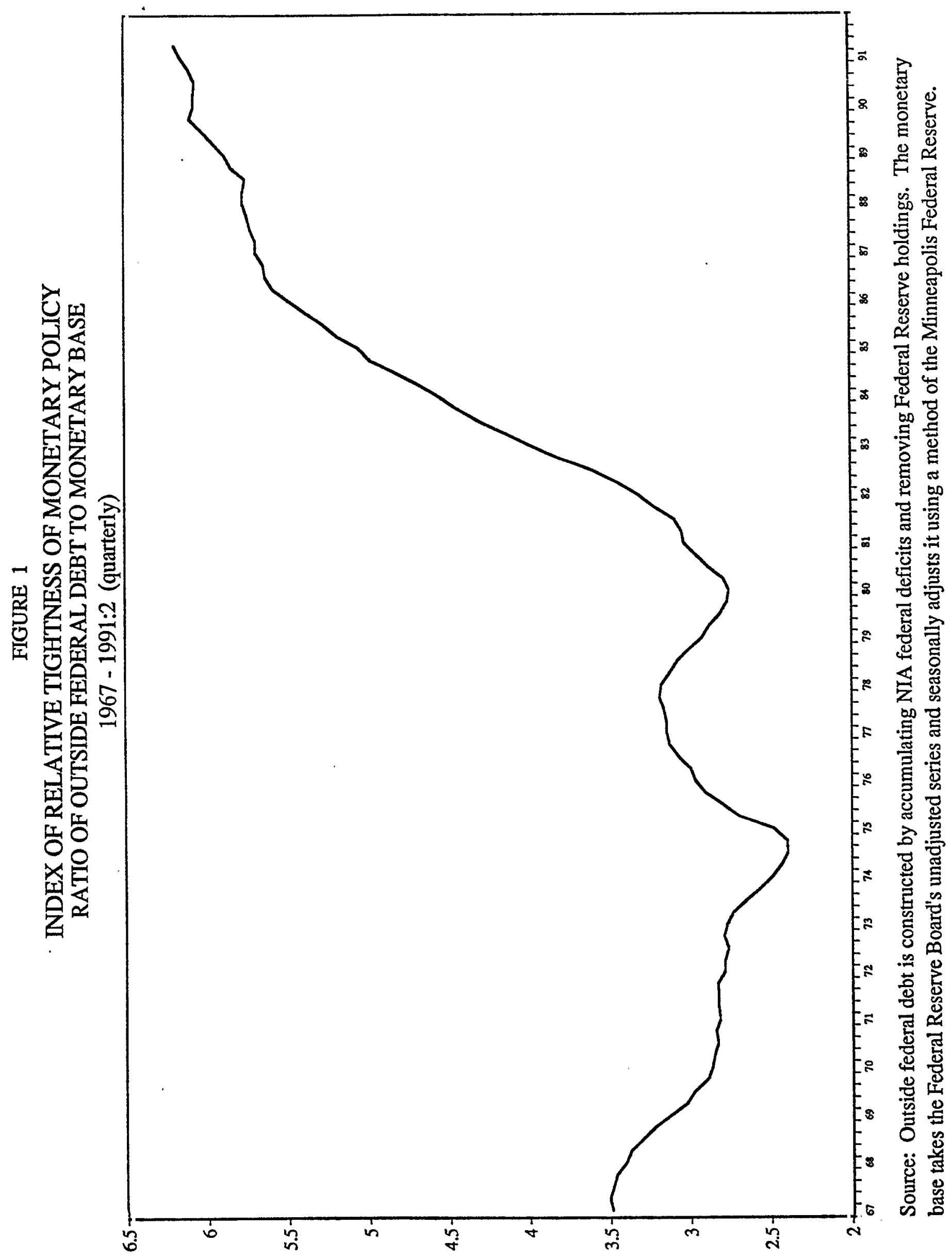




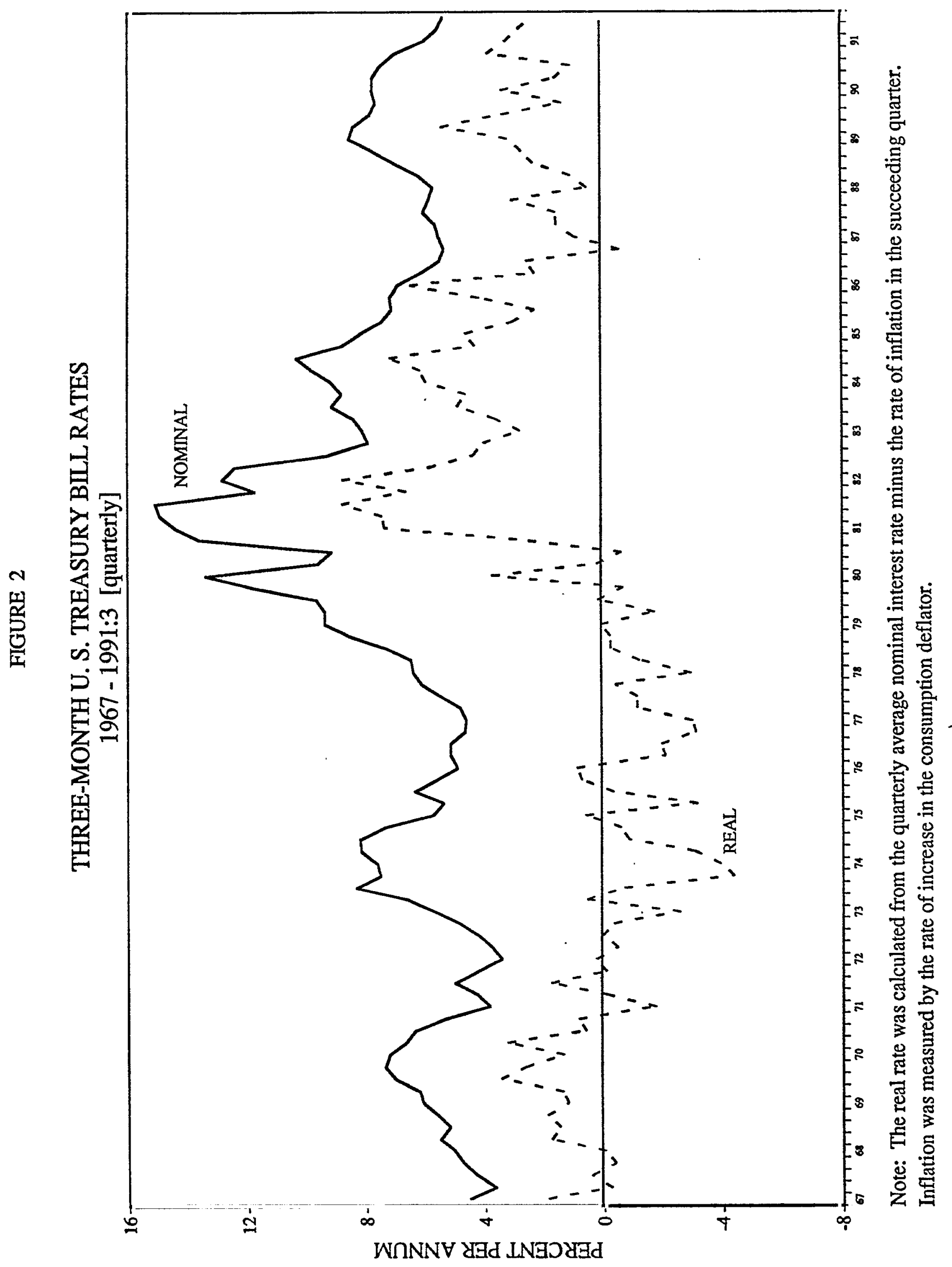




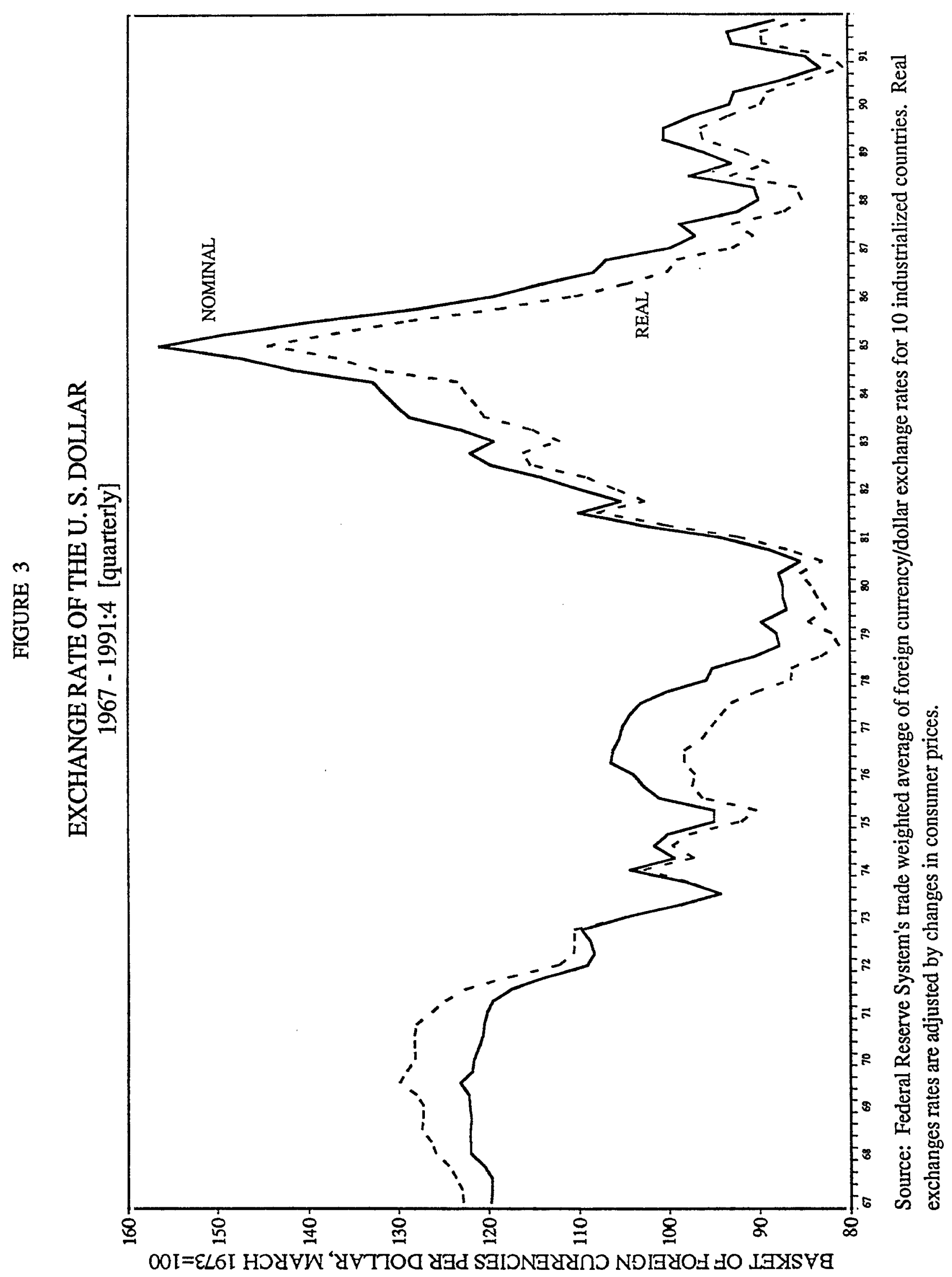




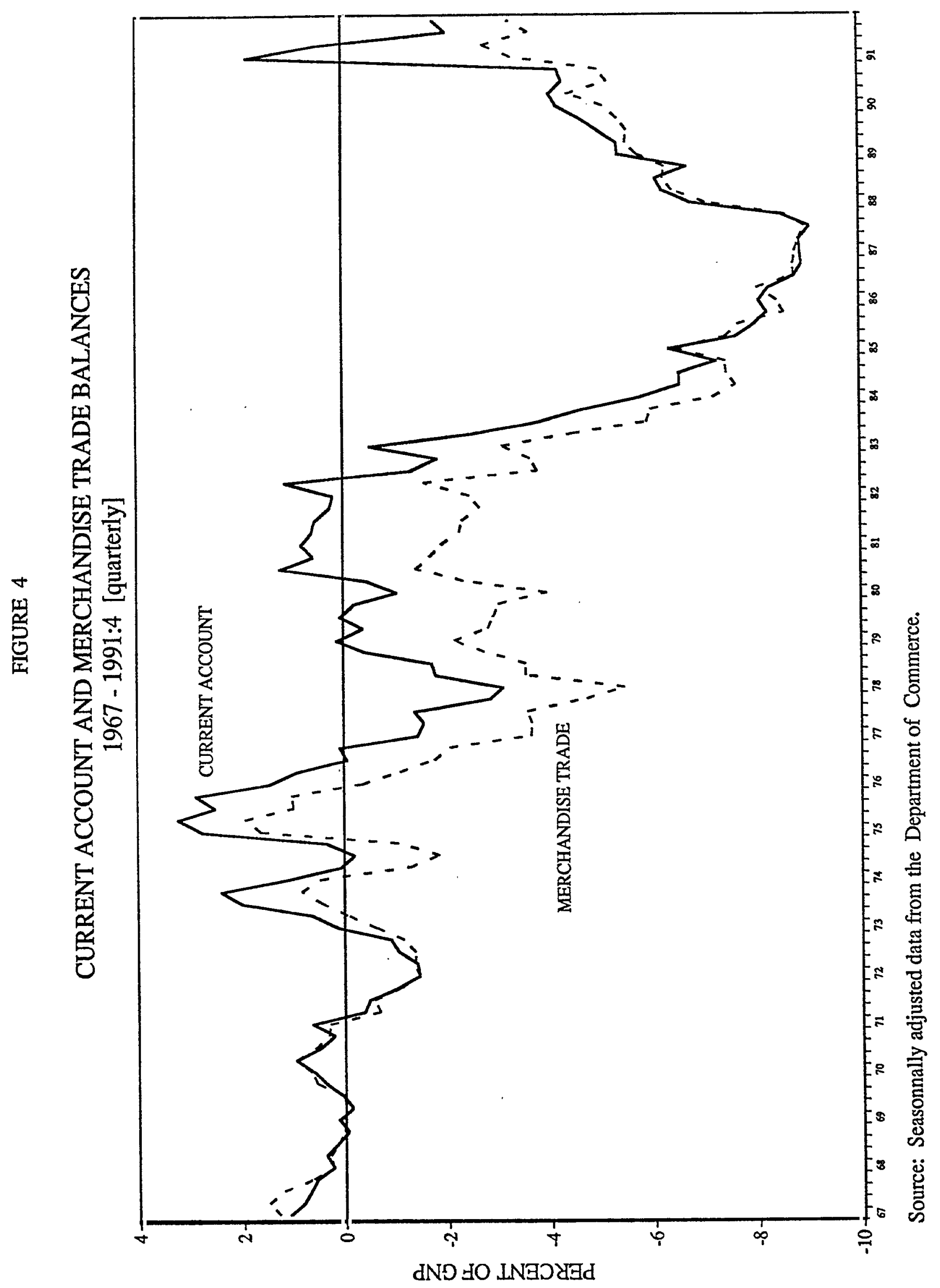



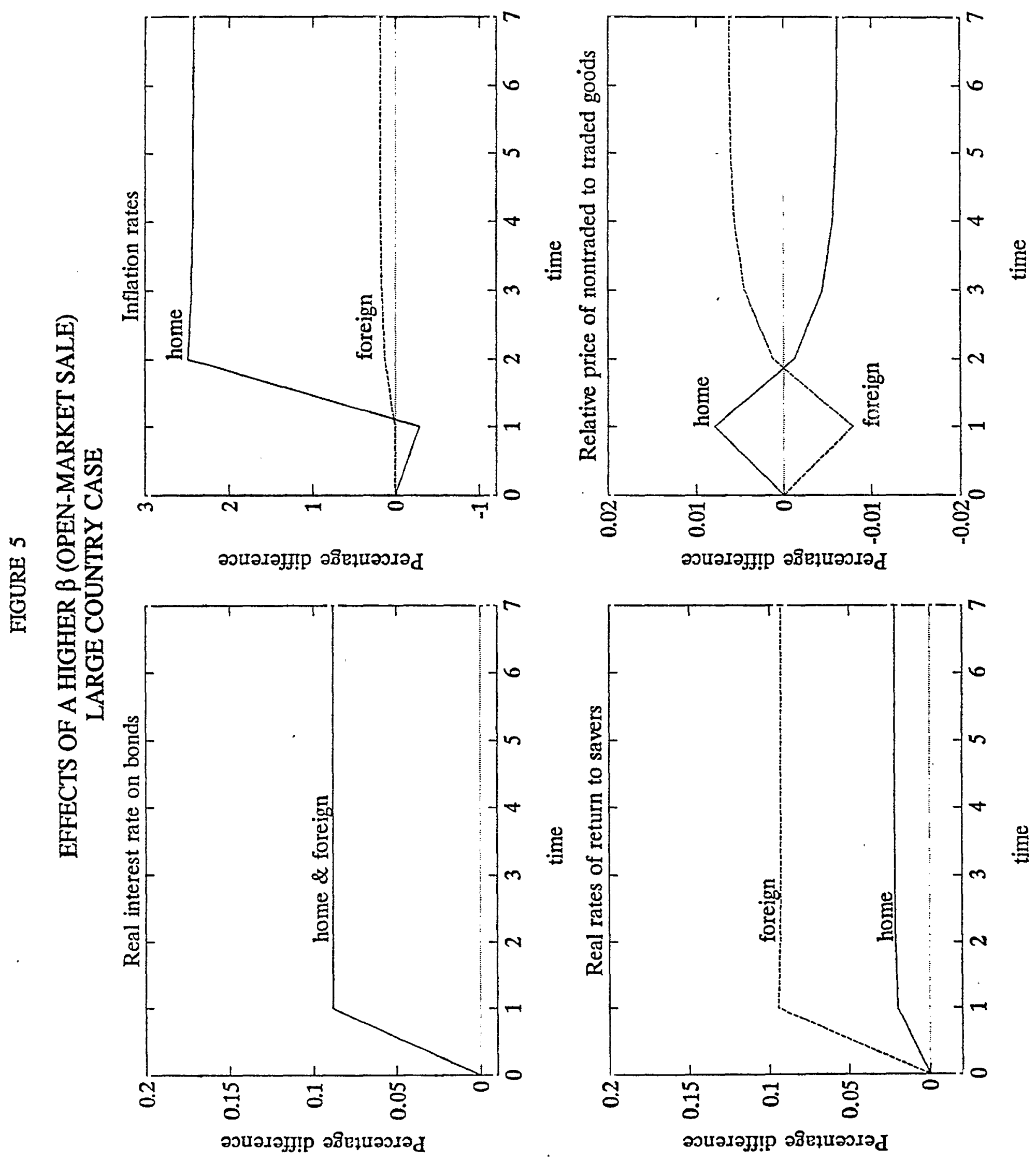


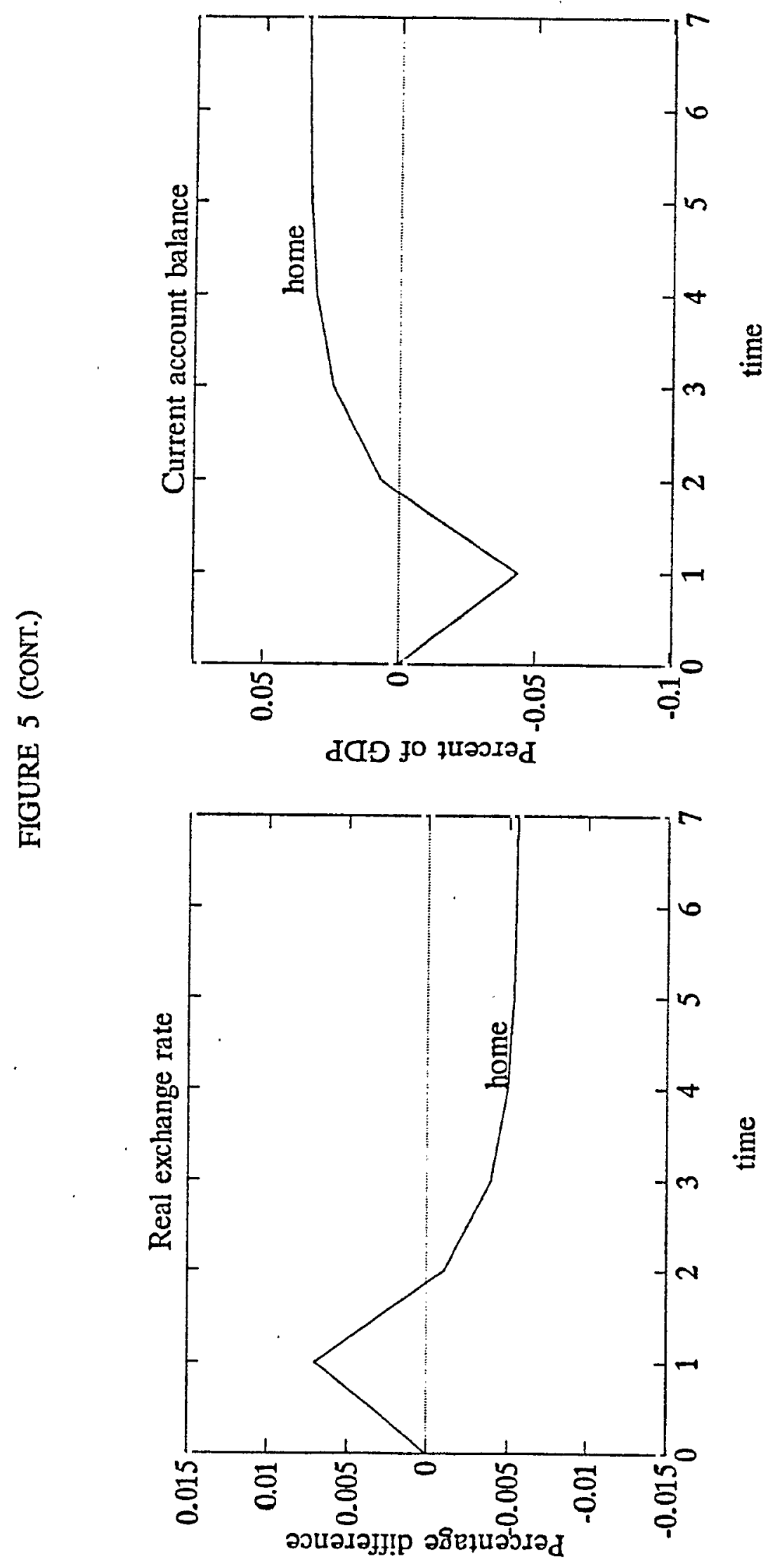



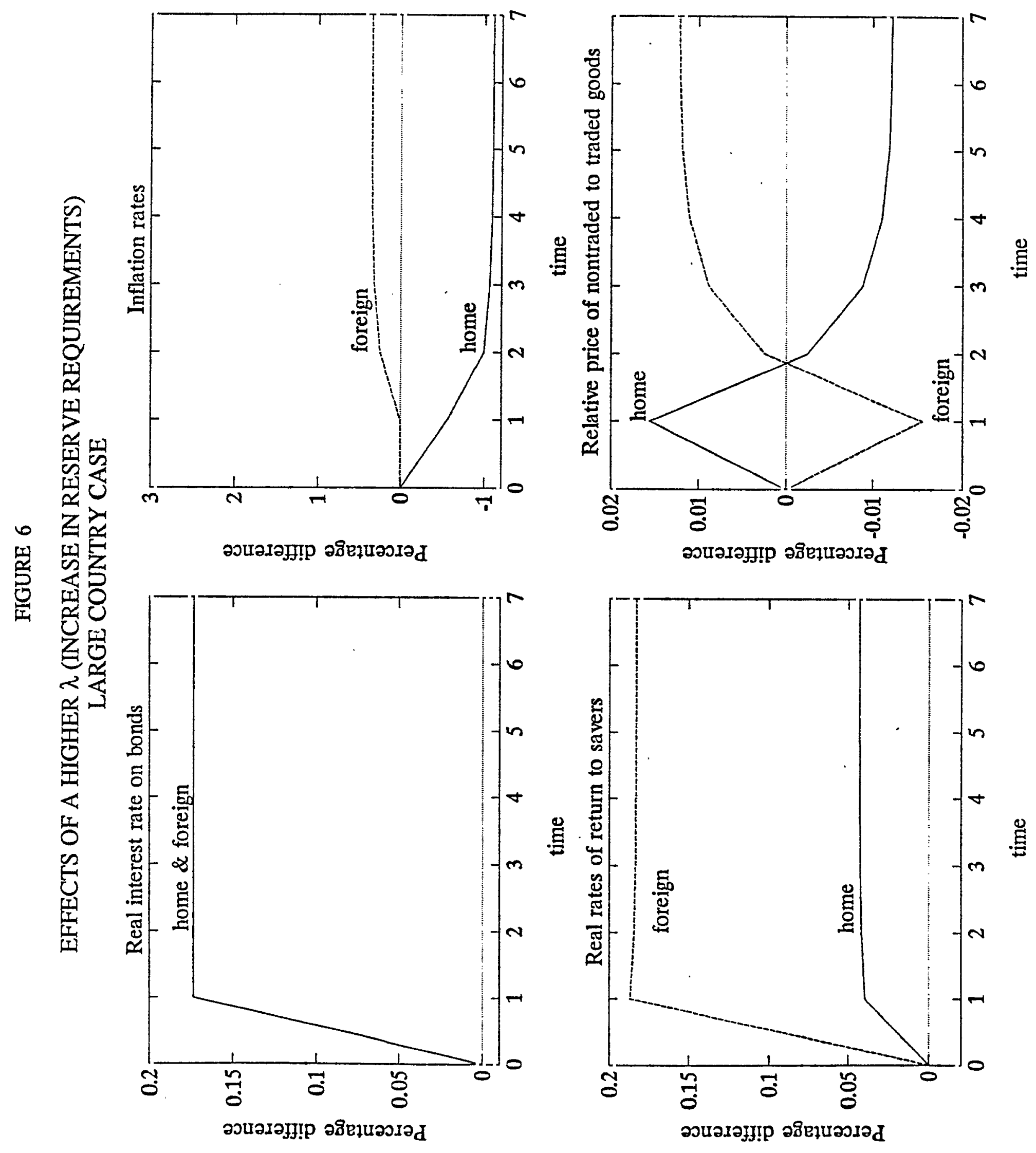

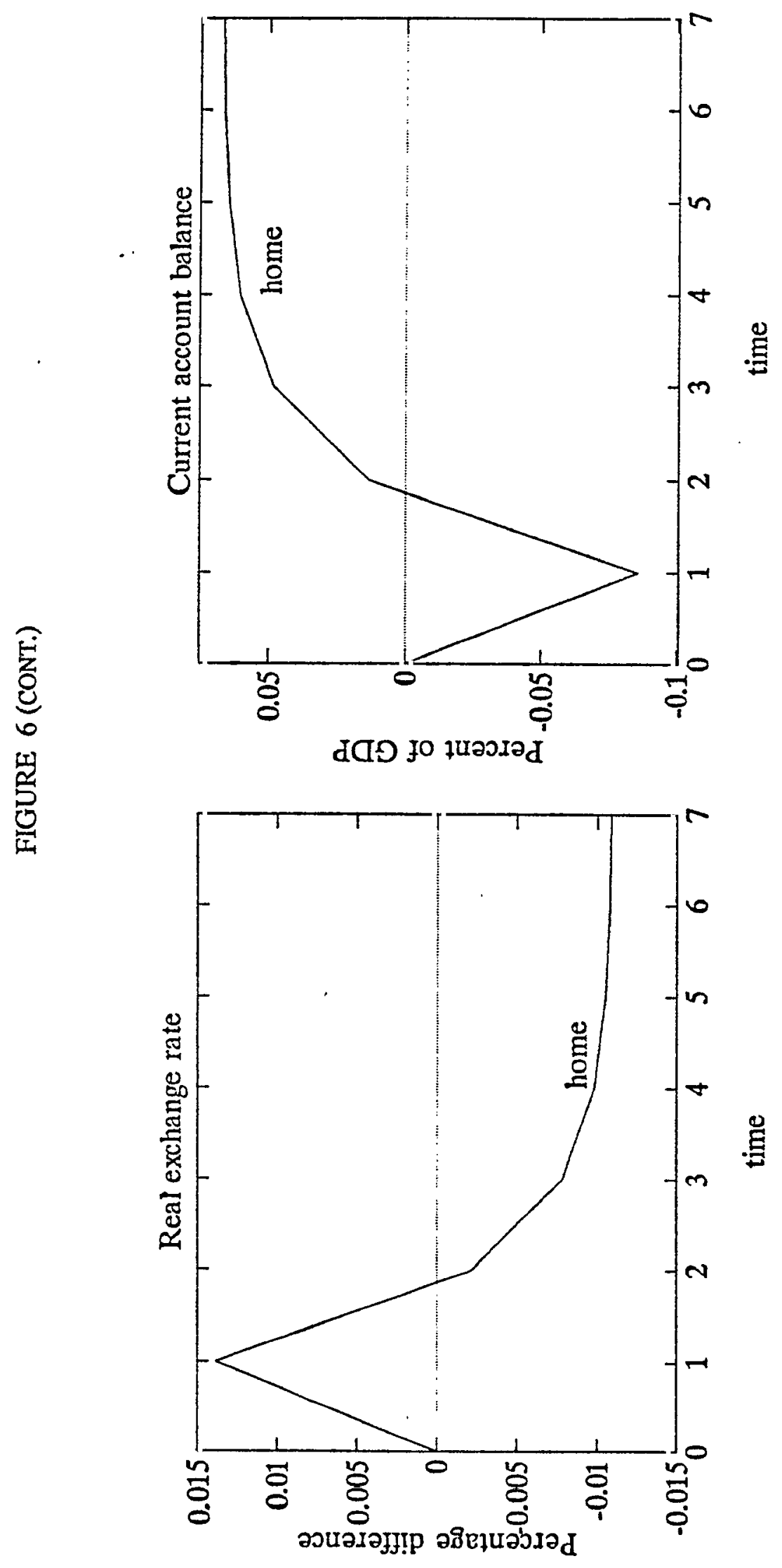


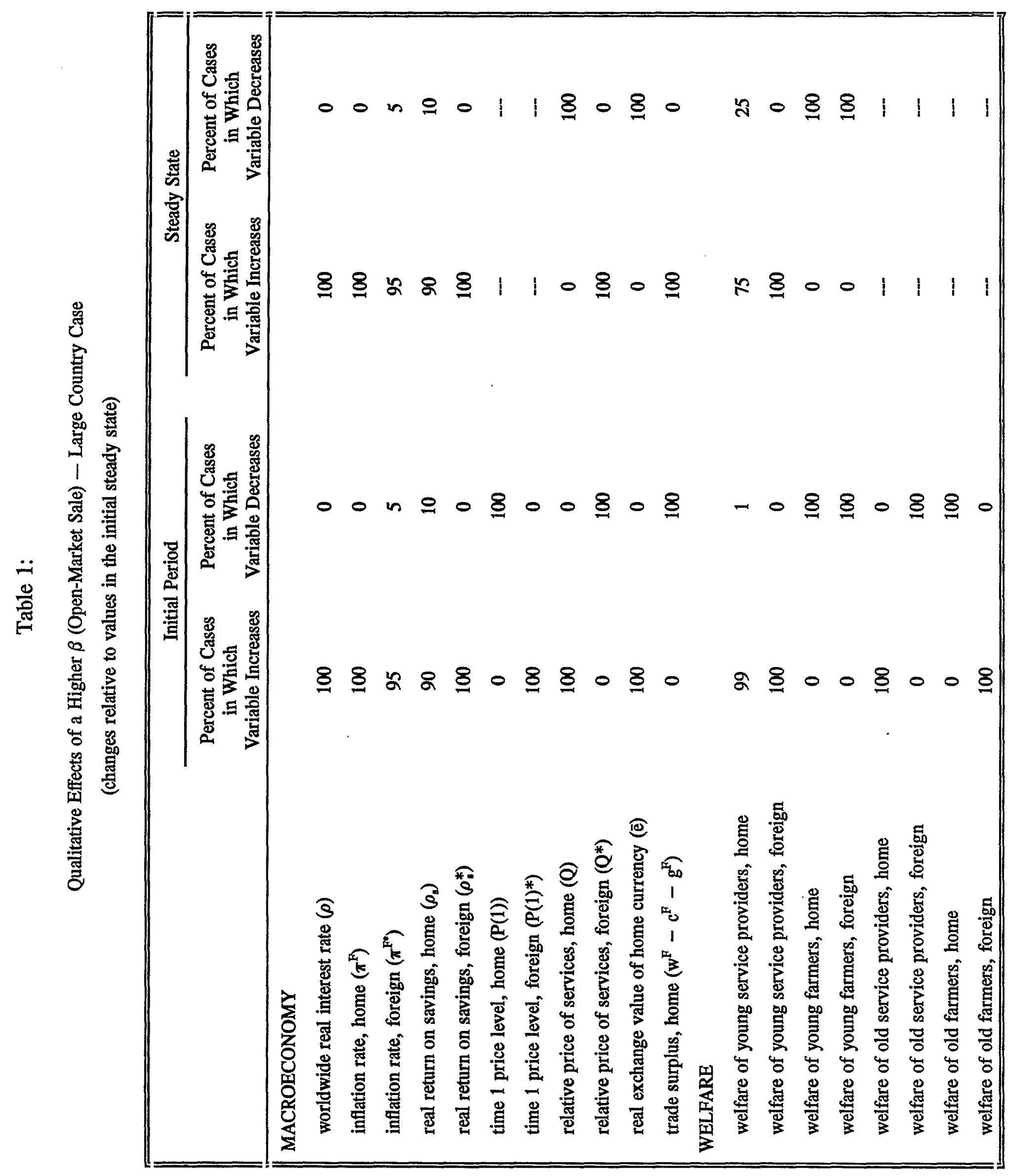




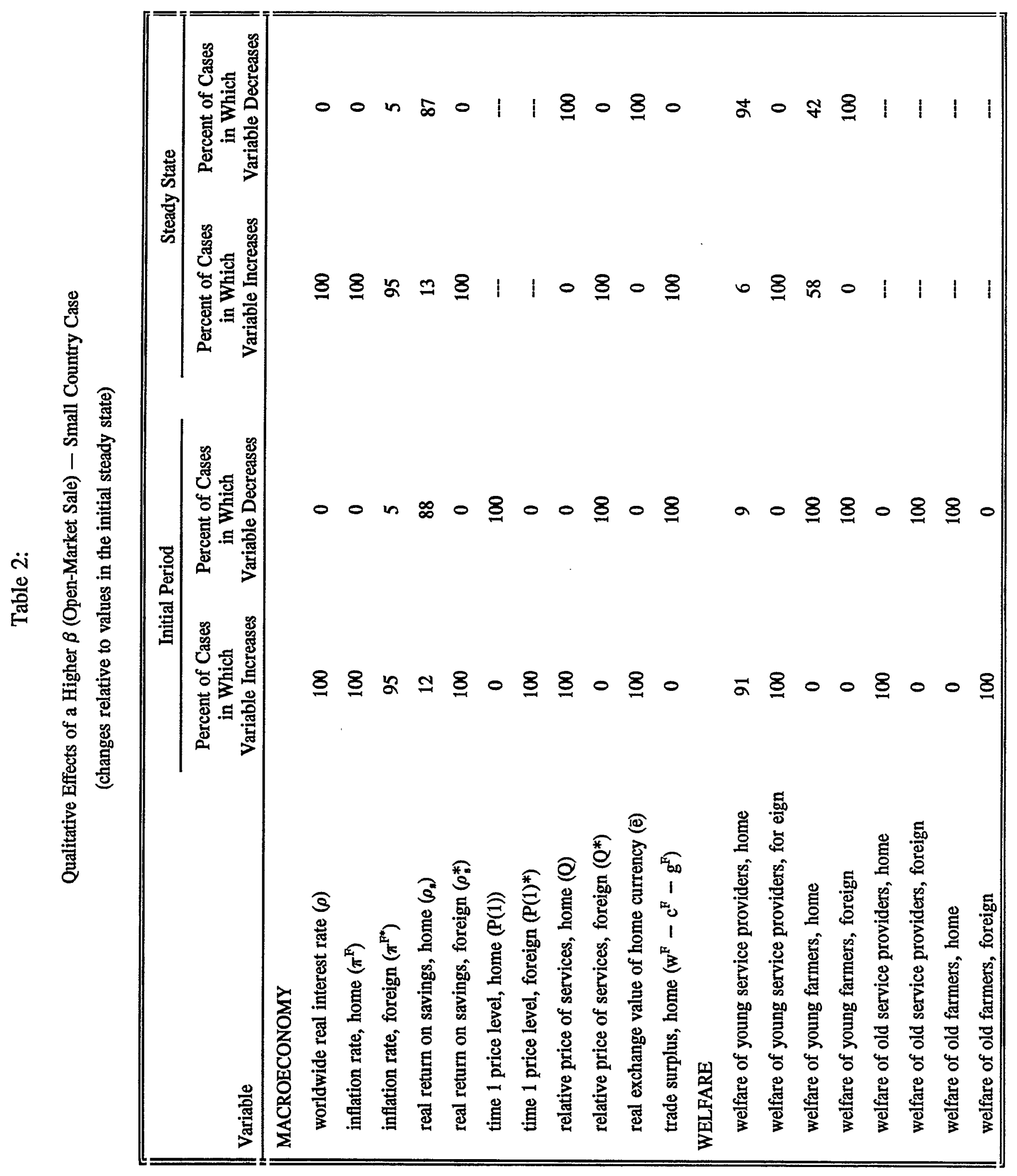




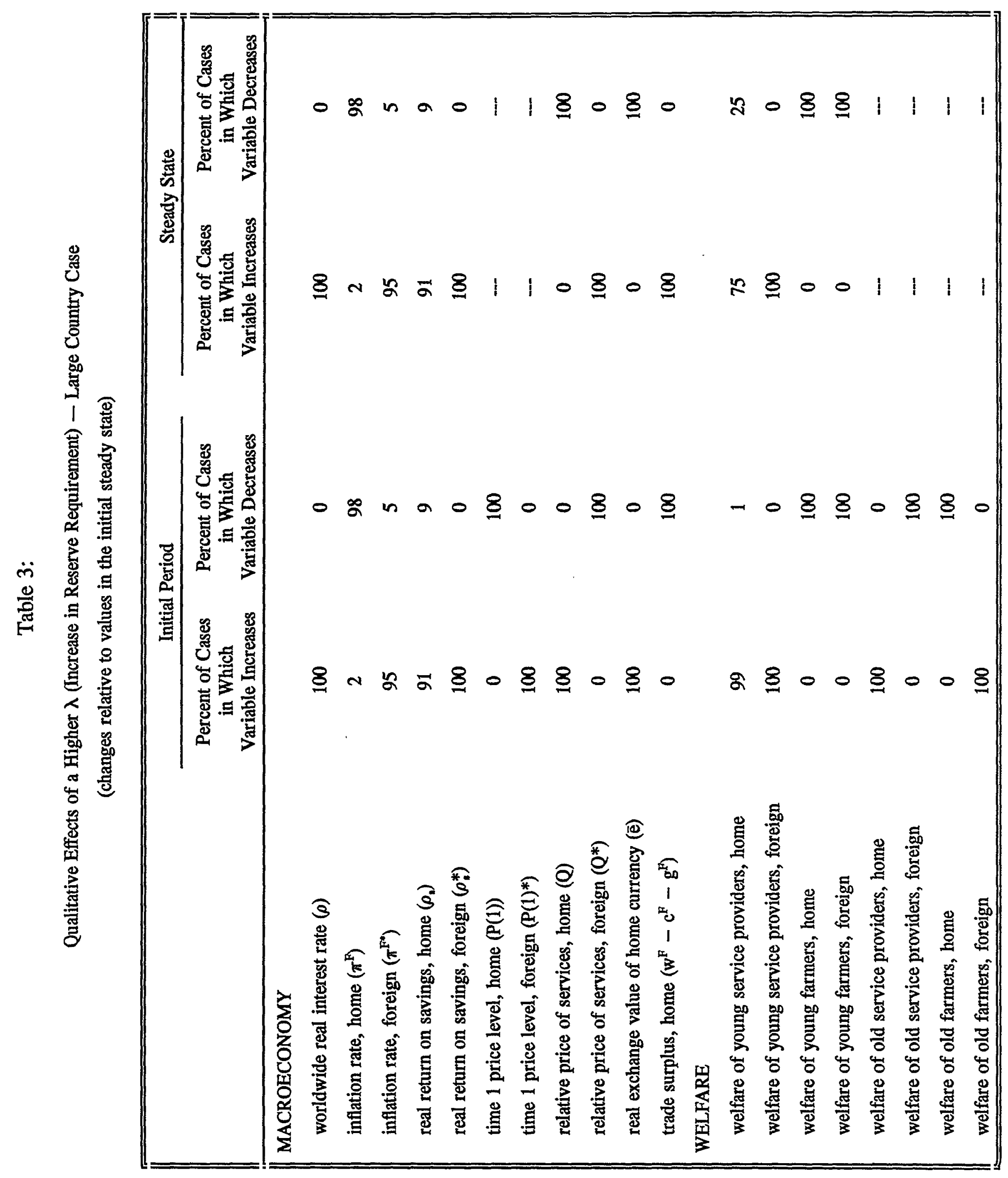




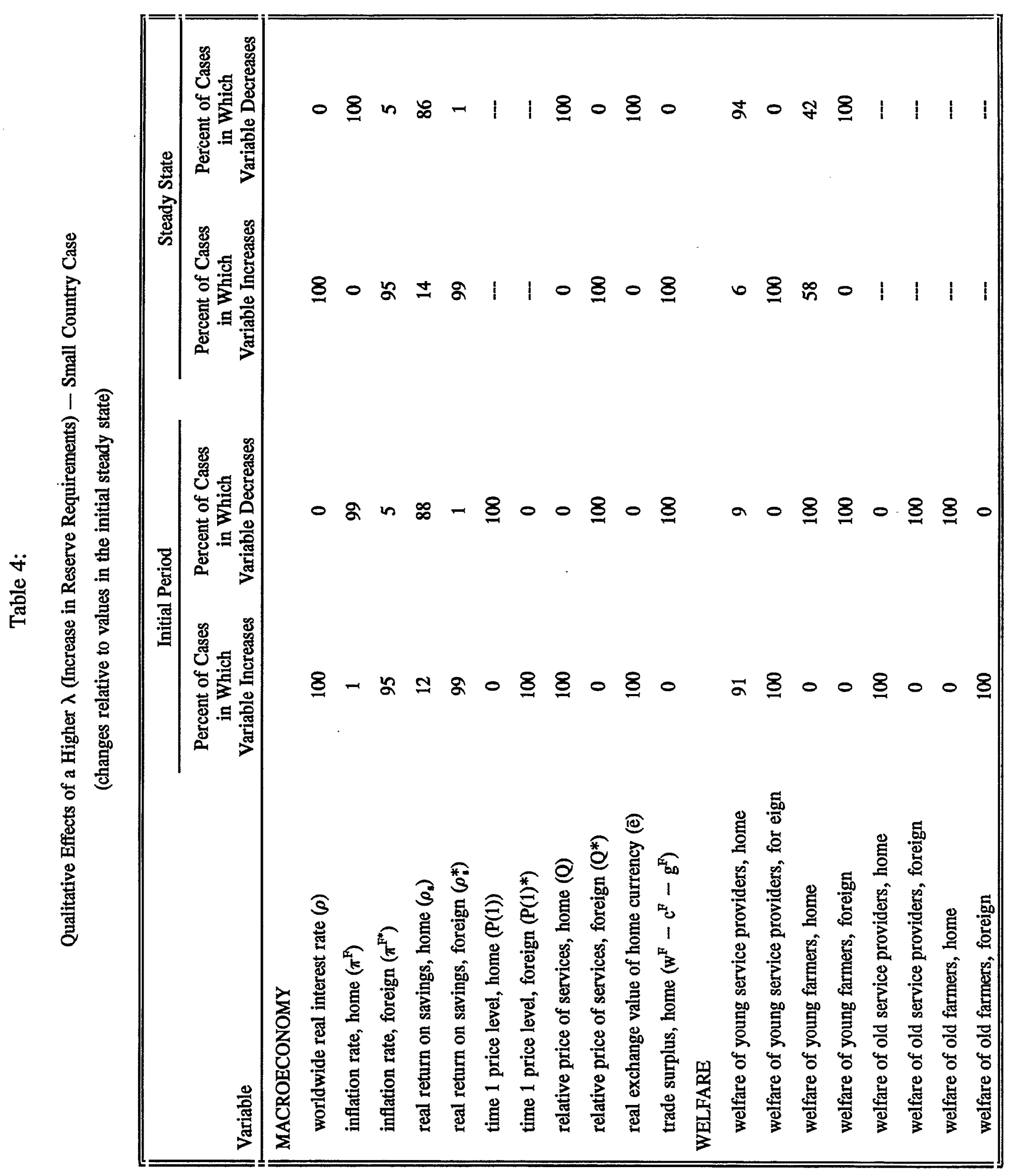

